\title{
Identifying flood recharge and inter-aquifer connectivity using multiple isotopes in subtropical Australia
}

\author{
A. C. King ${ }^{1,2}$, M. Raiber ${ }^{1,2,3}$, D. I. Cendón ${ }^{4,5}$, M. E. Cox ${ }^{1,2}$, and S. E. Hollins ${ }^{4}$ \\ ${ }^{1}$ School of Earth, Environmental and Biological Sciences, Queensland University of Technology (QUT), \\ Brisbane, QLD 4001, Australia \\ ${ }^{2}$ National Centre for Groundwater Research and Training (NCGRT), Adelaine, Australia \\ ${ }^{3}$ CSIRO Land and Water, Dutton Park, Brisbane, QLD 4102, Australia \\ ${ }^{4}$ Australian Nuclear Science and Technology Organisation (ANSTO), Menai, Sydney, NSW 2234, Australia \\ ${ }^{5}$ Connected Water Initiative, School of Biological, Earth and Environmental Sciences, University of New South Wales \\ (UNSW), Sydney, NSW 2052, Australia
}

Correspondence to: A. C. King (akingac@gmail.com)

Received: 4 February 2014 - Published in Hydrol. Earth Syst. Sci. Discuss.: 1 April 2014

Revised: 18 March 2015 - Accepted: 3 April 2015 - Published: 19 May 2015

\begin{abstract}
An understanding of hydrological processes is vital for the sustainable management of groundwater resources, especially in areas where an aquifer interacts with surface water systems or where aquifer interconnectivity occurs. This is particularly important in areas that are subjected to frequent drought/flood cycles, such as the Cressbrook Creek catchment in Southeast Queensland, Australia. In order to understand the hydrological response to flooding and to identify inter-aquifer connectivity, multiple isotopes $\left(\delta^{2} \mathrm{H}, \delta^{18} \mathrm{O},{ }^{87} \mathrm{Sr} /{ }^{86} \mathrm{Sr},{ }^{3} \mathrm{H}\right.$ and $\left.{ }^{14} \mathrm{C}\right)$ were used in this study in conjunction with a comprehensive hydrochemical assessment, based on data collected 6 months after severe flooding in 2011. The relatively depleted stable isotope signatures of the flood-generating rainfall $\left(\delta^{2} \mathrm{H}:-30.2\right.$ to $-27.8 \%, \delta^{18} \mathrm{O}$ : -5.34 to $-5.13 \%$ VSMOW) were evident in surface water samples $\left(\delta^{2} \mathrm{H}:-25.2\right.$ to $-23.2 \%, \delta^{18} \mathrm{O}:-3.9$ to $-3.6 \%$ o VSMOW), indicating that these extreme events were a major source of recharge to the dam in the catchment headwaters. Furthermore, stable isotopes confirmed that the flood generated significant recharge to the alluvium in the lower part of the catchment, particularly in areas where interactions between surface waters and groundwater were identified and where diffuse aquifer recharge is normally limited by a thick (approximately $10 \mathrm{~m}$ ) and relatively impermeable unsaturated zone. However, in the upper parts of the catchment where recharge generally occurs more rapidly due to the dominance of coarse-grained sediments in the unsaturated
\end{abstract}

zone, the stable isotope signature of groundwater resembles the longer-term average rainfall values $\left(\delta^{2} \mathrm{H}:-12.6, \delta^{18} \mathrm{O}\right.$ : $-3.4 \%$ VSMOW), highlighting that recharge was sourced from smaller rainfall events that occurred subsequent to the flooding. Interactions between the bedrock aquifers and the alluvium were identified at several sites in the lower part of the catchment based on ${ }^{87} \mathrm{Sr} /{ }^{86} \mathrm{Sr}$ ratios; this was also supported by the hydrochemical assessment, which included the modelling of evaporation trends and saturation indices. The integrated approach used in this study facilitated the identification of hydrological processes over different spatial and temporal scales, and the method can be applied to other complex geological settings with variable climatic conditions.

\section{Introduction}

Alluvial aquifers are natural reservoirs of groundwater, buffering baseflow in river systems and providing a reliable water supply during drier climatic phases (Winter et al., 1998). Moreover, interactions between alluvial aquifers and their connected streams are essential for the maintenance of healthy surface water and groundwater ecosystems (Boulton et al., 1998, 2010; Hancock et al., 2005; Anibas et al., 2012). Sustainable management of these alluvial aquifers is critical, but to enable this, a good understanding of recharge processes is required, together with an appreciation of the dif- 
ferent groundwater sources and the spatial variability of this recharge (Hrachowitz et al., 2011; Dogramaci et al., 2012).

While it is generally recognised that recharge is variable over time, the influence of episodic climatic events such as flooding are not very well understood. This is particularly the case in alluvial aquifers where total recharge is often dominated by flood-related influxes (e.g. Workman and Serrano, 1999). In these alluvial systems, recharge rates are commonly elevated during floods, as a result of (1) the enhanced permeability of the creek bed during the flood, due to scouring of the clogging layer by high velocity flows (e.g. Cendón et al., 2010; Simpson and Meixner, 2012); (2) enlarged pathway between surface- and groundwater, due to the increased width of the creek and the interface between groundwater and the creek across which interaction can occur (e.g. Lange, 2005); and (3) the increased head gradient between the creek and the stream (e.g. Rushton and Tomlinson, 1979). Owing to this reliance on infrequent flooding and large rainfall events, alluvial aquifers are likely to be severely impacted by the predicted changes in climatic patterns, such as the projected increased frequency and severity of droughts and floods (Parry et al., 2007). This forecasted climate change will impact on river flows (Arnell and Gosling, 2013) and groundwater recharge processes (Green et al., 2011; Barron et al., 2012; Dawes et al., 2012). This is particularly relevant for alluvial systems which are connected to ephemeral or intermittent streams, as interactions between these streams and the alluvial aquifers are highly dependent on antecedent rainfalls (Hughes et al., 2011).

The study area is a small subtropical catchment in Southeast Queensland, Australia, which was subject to severe climate extremes in recent years, including an extended drought from the late 1990s through to approximately 2009, followed by heavy rains, which culminated in a $1 \%$ annual exceedance probability (AEP) flood in January 2011 (Babister and Retallick, 2011). This event provided a unique opportunity to study groundwater recharge processes that result from episodic flooding.

Seepage to the alluvium from the underlying bedrock aquifers is potentially an important source of recharge for the alluvium, but this process has not been verified. The influx of poor-quality groundwater, which is often associated with bedrock aquifers in the study area, may negatively impact on the water quality of the alluvial aquifer. Therefore, it is important to identify and monitor areas where bedrock seepage occurs.

The objective of this study is to demonstrate how multiple environmental isotopes $\left(\delta^{2} \mathrm{H}, \delta^{18} \mathrm{O},{ }^{87} \mathrm{Sr} /{ }^{86} \mathrm{Sr},{ }^{3} \mathrm{H}\right.$ and ${ }^{14} \mathrm{C}$ ) in combination with a comprehensive hydrochemical assessment can be applied to (1) assess the significance of floods as a major recharge source; (2) identify recharge processes and connectivity between surface water and groundwater; and (3) identify areas where the alluvium is recharged by the underlying highly diverse bedrock (inter-aquifer connectivity). Multiple isotopes are increasingly being used to identify inter-aquifer connectivity (e.g. Dogramaci and Herczeg, 2002; Raiber et al., 2009, Cartwright et al., 2010a, 2012; Costelloe et al., 2012; Baudron et al., 2014); nevertheless, studies of this kind are still challenging due to the complexity of the hydrochemical interactions that result from inter-aquifer groundwater flows.

Many studies have used surface- and groundwater compositions (i.e. isotopes, and major and minor ions) to report on the connection between streams and alluvial groundwater (e.g. Soulsby, 2007; Barrett et al., 1999; Kirchner et al., 2010; Mandal et al., 2011; Morgenstern et al., 2010; Siwek et al., 2011; Négrel and Petelet-Giraud, 2005). However, studies that use isotopes and hydrochemistry to assess the connectivity between alluvial aquifers and intermittent or ephemeral streams (e.g. Kumar et al., 2009; Vanderzalm et al., 2011), or report specifically on the effects of episodic groundwater recharge from flooding (e.g. Cartwright et al., 2010b; Cendón et al., 2010; Simpson et al., 2013) are less common. This study uses groundwater stable isotopes together with a detailed assessment of $\delta^{2} \mathrm{H}$ and $\delta^{18} \mathrm{O}$ in rainfall to assess episodic recharge. Rainfall isotope time series data are commonly used to assess long-term trends in groundwater recharge (e.g. Zhu et al., 2007; Praamsma et al., 2009); however, they are rarely applied to assess event recharge of shallow aquifers (e.g. Scholl et al., 2004; Gleeson et al., 2009). The value of considering time series data of rainfall stable isotopes in hydrogeological investigations is clearly demonstrated by this study, and the outcomes will be important for the management of the alluvial groundwater resources of the study area and for understanding flood-related processes in similar alluvial settings.

\section{Hydrogeological setting}

The Cressbrook Creek catchment covers an area of approximately $200 \mathrm{~km}^{2}$ in Southeast Queensland, Australia. The area considered for this study extends from the Cressbrook Dam in the headwaters to the confluence with the Brisbane River in the northeast; it excludes the area up-gradient of Cressbrook Dam, which is a drinking water supply dam for the Toowoomba City Council (Fig. 1). The topographically elevated areas in the southwest of the catchment (ranging from 220 to $520 \mathrm{~m}$ Australian Height Datum, AHD) are forested and mostly undeveloped, whereas alluvial plains along the drainage system host rich farm land $(>90 \%$ of the total alluvium by area), particularly in the lower part of the catchment to the northeast (approximately 70-150 m AHD). In this part of the catchment, irrigators use up to $3 \mathrm{GL}$ of alluvial groundwater annually (DNRM, 2012), but groundwater abstraction is often restricted due to low groundwater levels. With the construction of Cressbrook Dam in 1983, flow in Cressbrook Creek was further reduced, resulting in lower groundwater levels. While water was initially released from the dam to recharge the alluvium, releases were controver- 


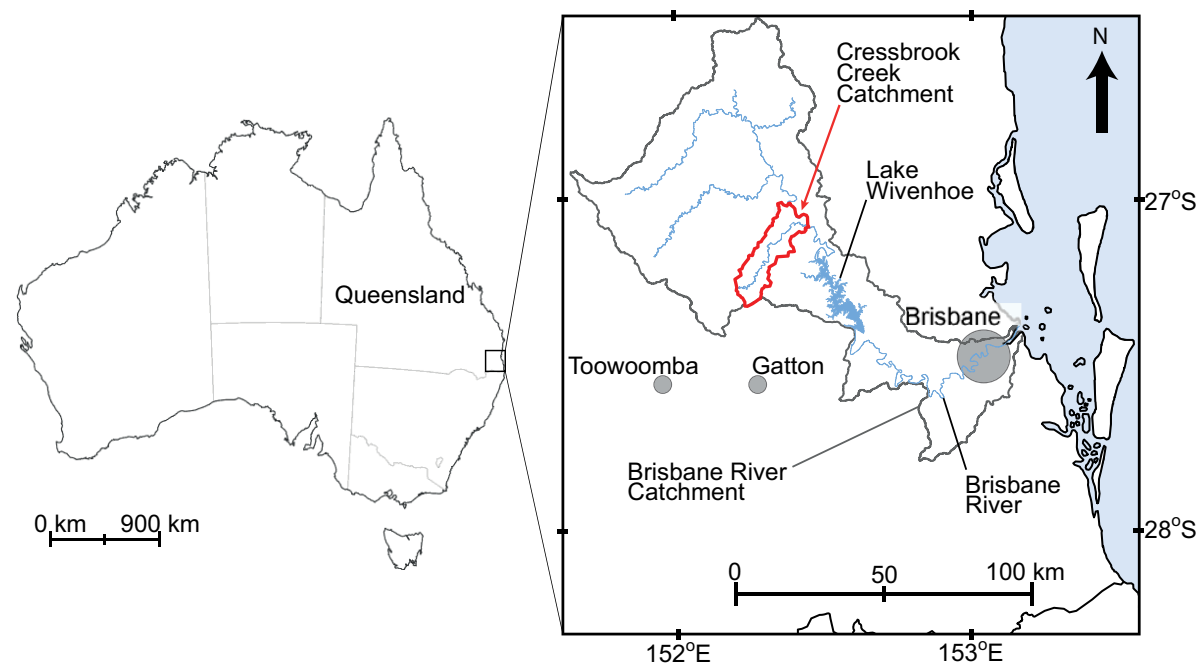

Figure 1. Cressbrook Creek catchment in Southeast Queensland, located approximately $80 \mathrm{~km}$ northwest of Brisbane and within the upper Brisbane River catchment.

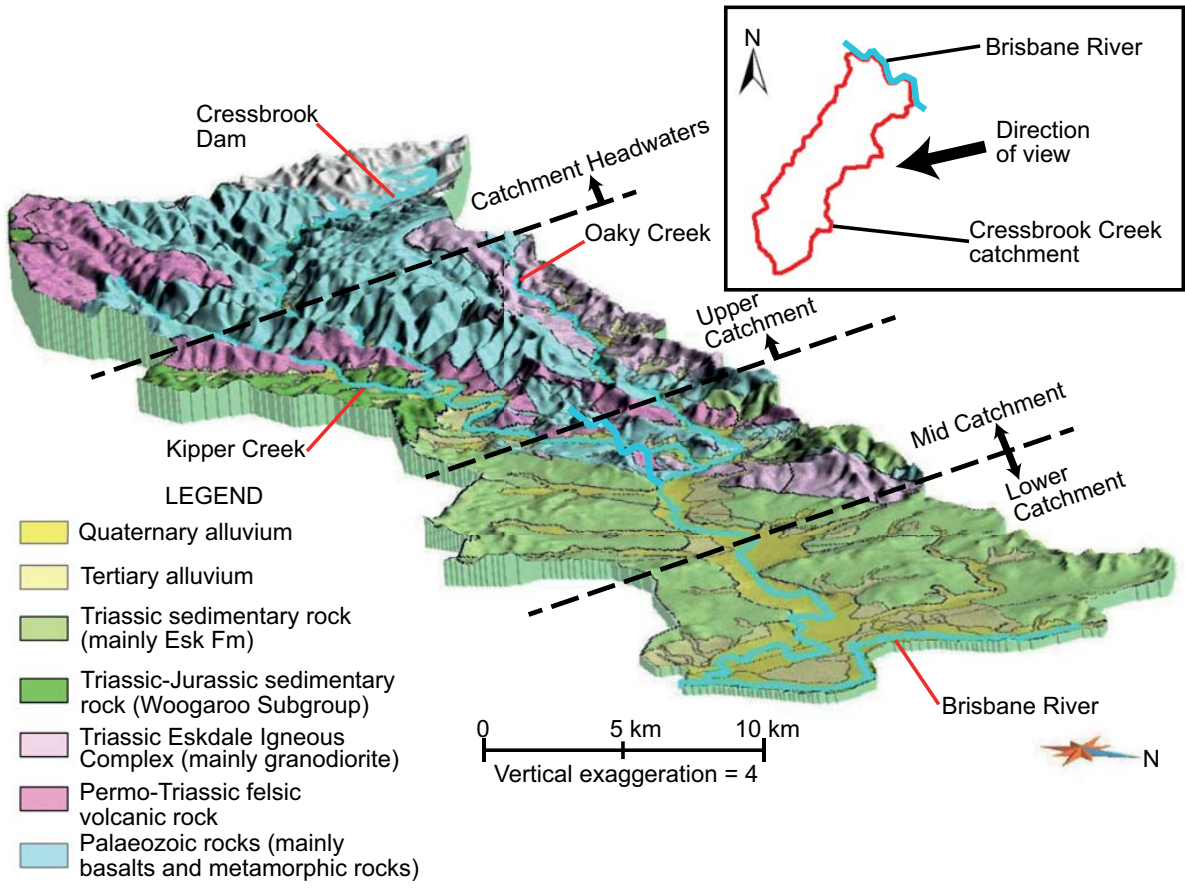

Figure 2. Geology, topography and surface drainages of the Cressbrook Creek catchment (viewed from the east; adapted from King et al., 2014).

sially phased out in the late 1990s due to drought-induced water shortages.

In this study, the catchment has been arbitrarily divided into four regions for ease of discussion: the catchment headwaters, the upper catchment, the mid catchment and the lower catchment (Fig. 2).

\subsection{Climate and surface water drainage}

Southeast Queensland is a subtropical region with hot, humid summers and dry, mild winters. The average annual rainfall at Toogoolawah in the lower part of the catchment (Fig. 3) is $847 \mathrm{~mm}$, although total annual rainfall can be highly variable, ranging from 366 to $1418 \mathrm{~mm}$ between 1909 and 2011 (Station number 040205; BOM, 2012). However, even in wet years the diffuse recharge is limited by high evapotran- 


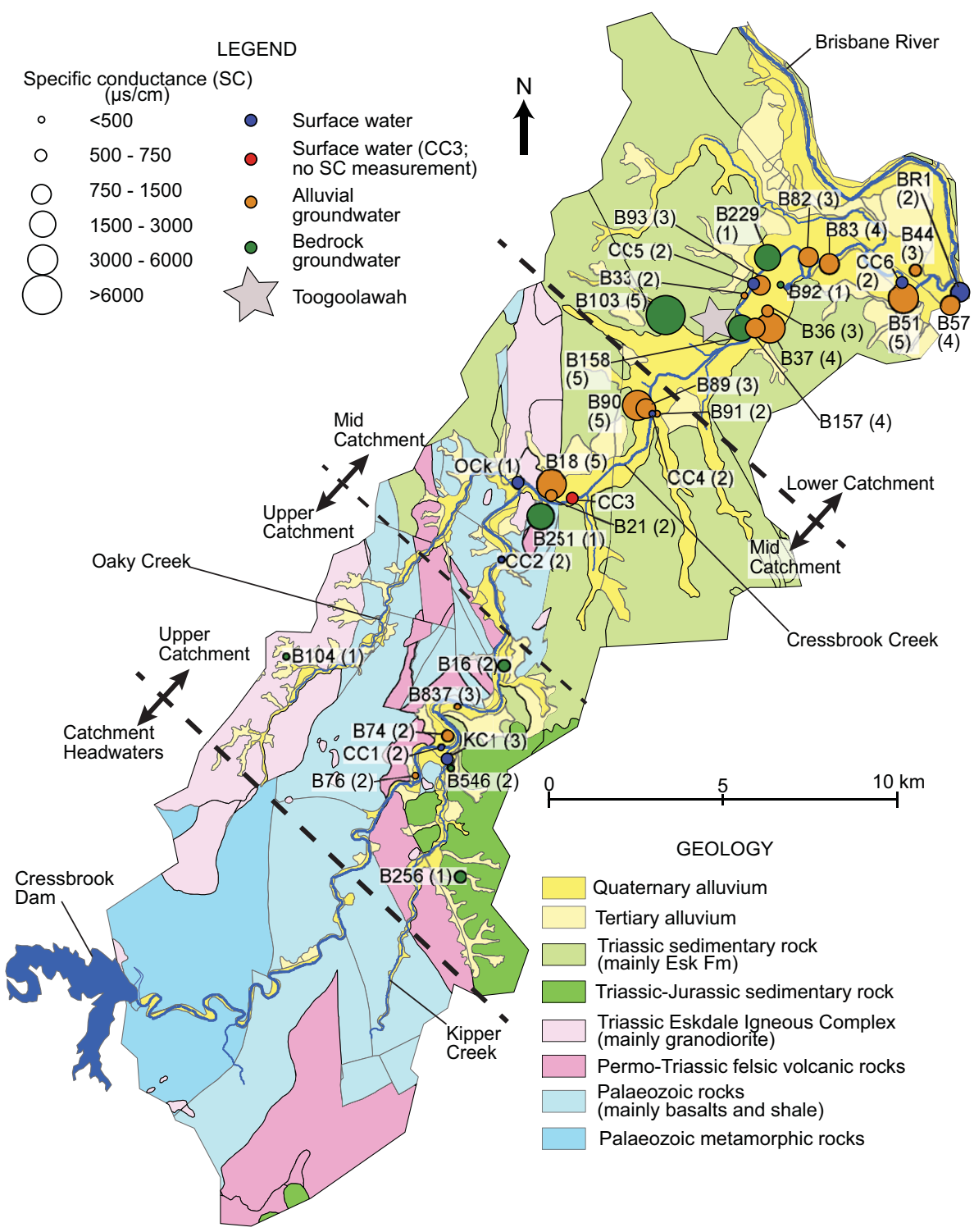

Figure 3. Location of sampling sites, and catchment-wide distribution of specific conductance (SC) and hydrochemical facies distribution (in parentheses; Sect. 5.1.1) in the Cressbrook Creek catchment. The samples were collected in June 2011 (see Table 3 for exact dates).

spiration rates, with mean annual pan evaporation rates of $1809 \mathrm{~mm}$ measured at Gatton (Fig. 1), located about $25 \mathrm{~km}$ to the south of the study area (Harms and Pointon, 1999).

This climatic variability has been particularly evident in recent years, when below average rainfall from 2000 to 2009 resulted in very low creek flow, especially from mid2006 until early 2008 when flow in the creek ceased completely (Fig. 4b). Due to that extended drought, water levels at Cressbrook Dam in the headwaters of the catchment (Fig. 2) did not reach the overflow in the period between 1999 and early 2011, and there was no flow from the dam to the creek. Despite the lack of outflow from the dam, intermittent flow was recorded in Cressbrook Creek during this period of time (Fig. 4b), indicating that the creek was recharged by both overland and groundwater contributions along its course. The period of drought was then followed by 2 wet years (2010 and 2011), culminating in significant flooding in January 2011 (Fig. 4b), approximately 5 months prior to the sampling conducted during this study. As a result of this flooding, Cressbrook Dam reached the overflow and discharged to Cressbrook Creek until 24 June 2011, with peak flows of approximately $330 \mathrm{~m}^{3} \mathrm{~s}^{-1}$. During the surface water sampling campaign (7-8 June 2011), approximately $0.5 \mathrm{~m}^{3} \mathrm{~s}^{-1}$ was discharging from Cressbrook Dam (Toowoomba Regional Council, 2012) and Cressbrook Creek was flowing at approximately $0.7 \mathrm{~m}^{3} \mathrm{~s}^{-1}$ at $\mathrm{CC} 3$ (Fig. 3; DNRM, 2013), indicating that the majority of flow in Cress- 


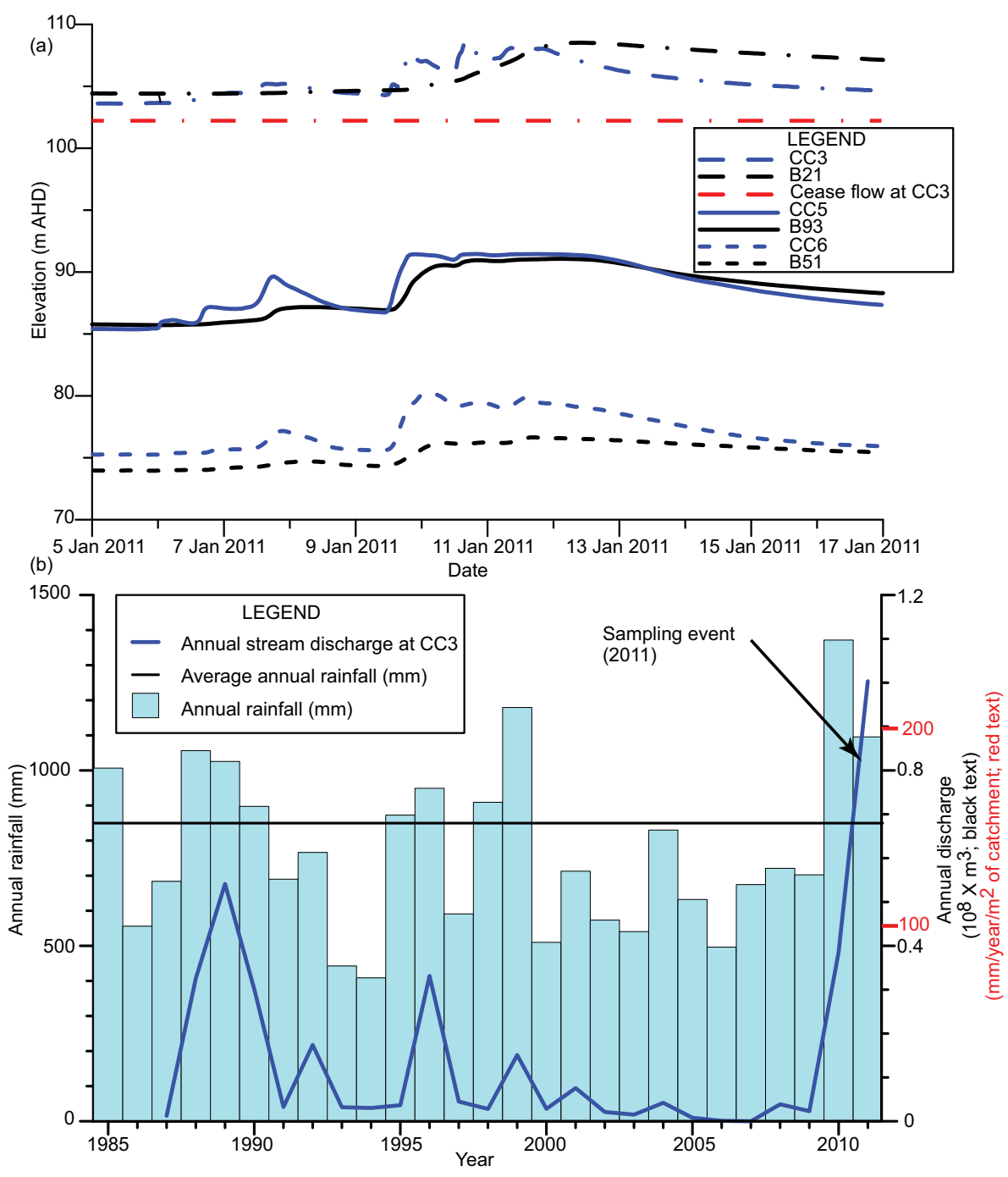

Figure 4. (a) Groundwater and stream hydrographs from the flood period; (b) annual rainfall (BOM, 2012) for the Cressbrook Creek catchment and annual stream discharge at CC3 (stream gauge 143921A; DNRM, 2012). Stream discharge is displayed in units of $\mathrm{m}^{3} \mathrm{yr}^{-1}$ and $\mathrm{mm} \mathrm{yr}^{-1} \mathrm{~m}^{-2}$ of catchment, assuming that the catchment area is $447 \mathrm{~km}^{2}$. Also shown is time of sampling.

brook Creek was probably derived from the dam during this period.

Groundwater hydrographs show that during the peak of the drought in 2008, groundwater levels had dropped to approximately $4-5 \mathrm{~m}$ below the base of the creek in the lower catchment. Additionally, the groundwater gradient in the lower catchment indicated that the creek was losing during this drought period. However, groundwater levels recovered following the flooding and heavy rain in 2010 to 2011. Subsequent to the flood, the groundwater gradient reversed and Cressbrook Creek became a gaining stream in the mid to lower catchment (Fig. 3), suggesting that groundwater gradients between the alluvial aquifer and stream are dynamic and dependent on the antecedent rainfall conditions. However, it is apparent that the alluvium receives substantial recharge from Cressbrook Creek in the mid to lower catchment (King et al., 2014).

\subsection{Geology}

\subsubsection{Bedrock}

The alluvial aquifer system of Cressbrook Creek overlies bedrock of variable geology, with volcanic rocks, metamorphic rocks and granodiorite prominent in the upper part of the catchment (Figs. 2 and 3). Basaltic rocks are particularly prominent in the upper catchment, whereas the bedrock in the mid to lower catchment is composed mainly of the Mesozoic sedimentary rocks of the Esk Formation. Primary porosities of these bedrock units are generally low, but permeabilities are enhanced in some regions by weathering of granodiorites and fracturing in other rocks (GSQ and IWSC, 1973). 
Table 1. Geological description of bedrock hydrochemical sampling sites (DNRM, 2012).

\begin{tabular}{llllr}
\hline ID & $\begin{array}{l}\text { DNRM aquifer } \\
\text { description }\end{array}$ & $\begin{array}{l}\text { DNRM aquifer } \\
\text { interpretation }\end{array}$ & Inferred aquifer & $\begin{array}{c}\text { Depth of well } \\
\text { (metres below ground level) }\end{array}$ \\
\hline B16 & Conglomerate & Esk Fm & Esk Fm & 10.0 \\
B92 & Alluvium $(0.4 \mathrm{~m})$ sandstone $(2.6 \mathrm{~m})$ & Alluvium Esk Fm & Both alluvium and the Esk Fm & 14.2 \\
B158 & Alluvium $(2.0 \mathrm{~m})$ sandstone $(1.0 \mathrm{~m})$ & Alluvium Esk Fm & Both alluvium and the Esk Fm & 13.6 \\
B103 & Sandstone & Esk Fm & Esk Fm & 24.7 \\
B229 & No record & No record & Esk Fm & $>50.0$ \\
B256 & Basalt and shale & No record & Pinecliff Fm & 40.5 \\
B546 & Basalt & No record & Pinecliff Fm & 68.6 \\
B104 & Granite & No record & Eskdale Igneous Complex & 64.0 \\
B251 & Shale & No record & Maronghi Creek beds & 49.5 \\
\hline
\end{tabular}

The screened (slotted) section is $3 \mathrm{~m}$ long at B92 and B158. The values in parentheses in column 2 represent the length of the screened section that is encompassed by each geological material.

The Esk Formation underlies many of the alluvial sampling sites in the mid to lower catchment (Fig. 3), and has a broad range of sedimentary strata and grain sizes (Cranfield et al., 2001). Geological borehole logs (DNRM, 2012) confirm that this formation is very heterogeneous, with clayey sandstones, feldspathic sandstones, shale and basalt, all recorded at shallow depths within the mid to lower catchment.

\subsubsection{Alluvium}

The alluvial system at Cressbrook Creek is characterised by fining-upwards sequences, which typically consist of basal sands and gravels, overlain by silts and clays. Minor carbonate veins have been identified within granodiorites (Zahawi, 1972). However, their contribution to the alluvium, if any, has not been detected in X-ray diffraction (XRD) analyses of sediments collected from Lake Wivenhoe, which is located downstream of the confluence with the Cressbrook Creek and the Brisbane River (Fig. 1). In addition, no carbonate was detected in the weathered granodiorite profile (Douglas et al., 2007) as any potential carbonate particles are likely to dissolve. This apparent lack of carbonates implies that radiocarbon dating of alluvial groundwaters is unlikely to be significantly affected by interactions with carbonate minerals.

King et al. (2014) describe this complex, multi-layered alluvial system as a two-layer system based on sediment grain size assessment. The basal coarse-grained layer consists mostly of sands and gravels, whereas the upper low permeability layer is primarily composed of fine-grained sediments such as silts and clays. This fining upwards sequence is characteristic of many alluvial systems in eastern Australia (e.g. Cendón et al., 2010; Cox et al., 2013), largely due to diminishing surface water flows in the late Quaternary (Knighton and Nanson, 2000; Maroulis et al., 2007; Nanson et al., 2008). The thickness of the low-permeability layer increases with distance downstream, whereas the thickness of the basal high-permeability layer decreases down-gradient; these variations suggest that there is probably less recharge in the lower parts of the catchment compared to the upper parts.

\section{Water sampling and analytical methods}

Surface- and groundwater samples were collected in June and September 2011 from eight surface water sites, 18 bores screened in the alluvial aquifer and eight bedrock bores. In addition, two samples were collected from bores where the screened intervals (slotted section of casing) encompass both the lower 1-2 $\mathrm{m}$ of the alluvium and the top 1-2 $\mathrm{m}$ of the bedrock (B92 and B158); these sites are categorised as "bedrock sites" (Fig. 3). Alluvial boreholes are less than $20 \mathrm{~m}$ deep and they usually have a $3 \mathrm{~m}$ long screened section at the base of the alluvium, whereas bedrock boreholes are generally deep, except for three shallow bores screened in the Esk Formation (Table 1).

Prior to sampling, three well volumes were pumped from the boreholes and the specific (electrical) conductance (SC), temperature, redox potential (Eh) and $\mathrm{pH}$ were monitored using a flow cell to ensure that these parameters had stabilised prior to sampling. Field measurements were taken with a TPS 90 FL field meter, which was calibrated in accordance with the manufacturer's specifications prior to use.

\subsection{Major and minor ions}

Samples for major and minor cations ( $\mathrm{Na}, \mathrm{K}, \mathrm{Ca}, \mathrm{Mg}, \mathrm{Fe}$, $\mathrm{Mn}, \mathrm{Al}$ and $\mathrm{Sr}$ ) were collected in acid-cleaned $125 \mathrm{~mL} \mathrm{HDPE}$ (high-density polyethylene) bottles and acidified to approximately $\mathrm{pH} 2$ using $\mathrm{HNO}_{3}$. Cations were analysed at Queensland University of Technology (QUT) by inductively coupled plasma optical emission spectroscopy (ICP-OES). Samples for major anion analyses $\left(\mathrm{Cl}, \mathrm{NO}_{3}, \mathrm{SO}_{4}\right.$ and $\left.\mathrm{HCO}_{3}\right)$ were collected in pre-rinsed $250 \mathrm{~mL}$ HDPE bottles, with no further treatment until analysis, which was performed at QUT using an automated discrete analyser (Seal AQ2), ion chro- 
matography (Dionex ICS-2100) and by manual titration for alkalinity.

\subsection{Isotopes}

Stable isotopes $\left(\delta^{2} \mathrm{H}\right.$ and $\left.\delta^{18} \mathrm{O}\right)$ of groundwater and surface water samples collected during this study were analysed using a Los Gatos Liquid Water Isotope Analyser at the University of New South Wales (after Lis et al., 2008). The $\delta^{13} \mathrm{C}$ of dissolved inorganic carbon (DIC) was analysed at GNS Science (New Zealand). Strontium isotopes were analysed using multi-collector inductively coupled plasma mass spectrometry (MC-ICP-MS) at the University of Melbourne following the methods described by Hagedorn et al. (2011). The internal precision (2se) and external precision (2sd) for the MC-ICP-MS procedure is $\sim \pm 0.000020$ and \pm 0.000040 , respectively. Tritium and radiocarbon were analysed at the Australian Nuclear Science and Technology Organisation (ANSTO). For ${ }^{14} \mathrm{C}$ analysis, the total DIC was converted to $\mathrm{CO}_{2}$ using a custom-built extraction line. The $\mathrm{CO}_{2}$ sample was then graphitised, and graphite targets were analysed by AMS at ANSTO's STAR accelerator following procedures of Fink et al. (2004). Conventional radiocarbon ages were reported as percentage Modern Carbon (pMC) with $1 \sigma$ errors of less than 0.37 pMC (Stuiver and Polach, 1977). Samples for ${ }^{3} \mathrm{H}$ analysis were distilled and electrolytically enriched, and subsequently analysed using a liquid scintillation counter. Results are reported in tritium units (TU) with an uncertainty of $\pm 0.04-0.08 \mathrm{TU}$ and quantification limits of 0.13 TU.

Rainfall from Brisbane Airport was collected as a monthly composite of daily rain gauge samples, following the technical procedure recommended for GNIP sampling (http://www-naweb.iaea.org/napc/ih/documents/userupdate/ sampling.pdf). Samples from June to October 2010 were analysed by Isotope Ratio Mass Spectrometry at the CSIRO Land and Water Isotope Lab (Adelaide) (reported accuracy of \pm 1.0 and $\pm 0.15 \%$ or for $\delta^{2} \mathrm{H}$ and $\delta^{18} \mathrm{O}$, respectively) or Alberta Innovates Technology Futures Isotope Hydrology and Geochemistry Lab (reported accuracy of $\pm 1.0, \pm 0.2 \%$ o for $\delta^{2} \mathrm{H}$ and $\delta^{18} \mathrm{O}$, respectively). Samples from November 2010 to June 2011 were analysed at the ANSTO Institute for Environmental Research using a Cavity Ring-Down Spectroscopy method on a Picarro L2120-I Water Analyser (reported accuracy of \pm 1.0 and $\pm 0.2 \%$ ofor $\delta^{2} \mathrm{H}$ and $\delta^{18} \mathrm{O}$, respectively).

\subsection{Geochemical calculations}

Evaporation curves and saturation state calculations were performed using PHREEQC (Parkhurst and Appelo, 1999). Evaporation curves were calculated under the assumption that calcite, dolomite and gypsum precipitate when they reach saturation and are not re-dissolved. Mineral stability
Table 2. Hydraulic conductivities from falling/rising head tests in the alluvium of the Cressbrook Creek catchment.

\begin{tabular}{lccr}
\hline Well & $\begin{array}{c}\text { Hydraulic } \\
\text { conductivity }\left(\mathrm{m} \mathrm{d}^{-1}\right)\end{array}$ & $\begin{array}{c}\text { Catchment } \\
\text { area }\end{array}$ & $\begin{array}{r}\text { Distance from } \\
\text { surface water }(\mathrm{m})\end{array}$ \\
\hline B74 & 17 & Upper & 310 \\
B18 & 0.02 & Mid & 440 \\
B21 & 14 & Mid & 120 \\
B90 & 50 & Mid & 310 \\
B89 & 30 & Mid & 120 \\
B158 & 22 & Lower & 210 \\
B36 & 9.5 & Lower & 540 \\
B33 & 2 & Lower & 20 \\
B37 & 0.015 & Lower & 530 \\
B93 & 25 & Lower & 50 \\
B82 & 7.5 & Lower & 130 \\
B83 & 2.2 & Lower & 80 \\
B51 & 0.005 & Lower & 50 \\
B44 & 0.001 & Lower & 260 \\
B57 & 4 & Lower & 180 \\
\hline
\end{tabular}

diagrams were calculated after Drever (1997), using groundwater analyses collected as part of this study.

\section{Aquifer testing methodology}

Rising/falling head tests were conducted in order to estimate the hydraulic conductivity of the aquifer at each site. This information was consequently used to estimate recharge, as described later in the study. Rising head tests were conducted using a bailer, or, for the more permeable sites, two bailers joined end-to-end. Falling head tests were performed by pouring water into the bore, and the response was measured using a pressure transducer that recorded the water level at $1 \mathrm{~s}$ intervals. The hydraulic conductivity was then calculated using the Hvorslev method (Hvorslev, 1951).

\section{Results}

\subsection{Aquifer testing}

Hydraulic conductivity generally decreases with distance downstream, based on falling/rising head tests that were conducted as part of this study (Table 2). Also, the more permeable alluvium is generally located close to Cressbrook Creek.

\subsection{Hydrochemistry}

Surface waters are generally fresh $\left(\mathrm{SC}<850 \mu \mathrm{S} \mathrm{cm}^{-1}\right.$; Table 3) with similar proportions of major cations $(\mathrm{Na}, \mathrm{Ca}$ and $\mathrm{Mg}$; Fig. 5). The major anions are $\mathrm{Cl}$ and $\mathrm{HCO}_{3}$ and the $\mathrm{Cl} / \mathrm{HCO}_{3}$ molar ratio of water from Cressbrook Creek ranges from 0.92 to 1.35 , with ratios generally increasing with distance downstream. Alluvial groundwaters are fresh 


\section{LEGEND}

- Surface water

- Alluvial groundwater

- Esk Fm groundwater

- Granodiorite groundwater

- Other bedrock groundwater Scale of radii: Proportional to EC

- 0

5000

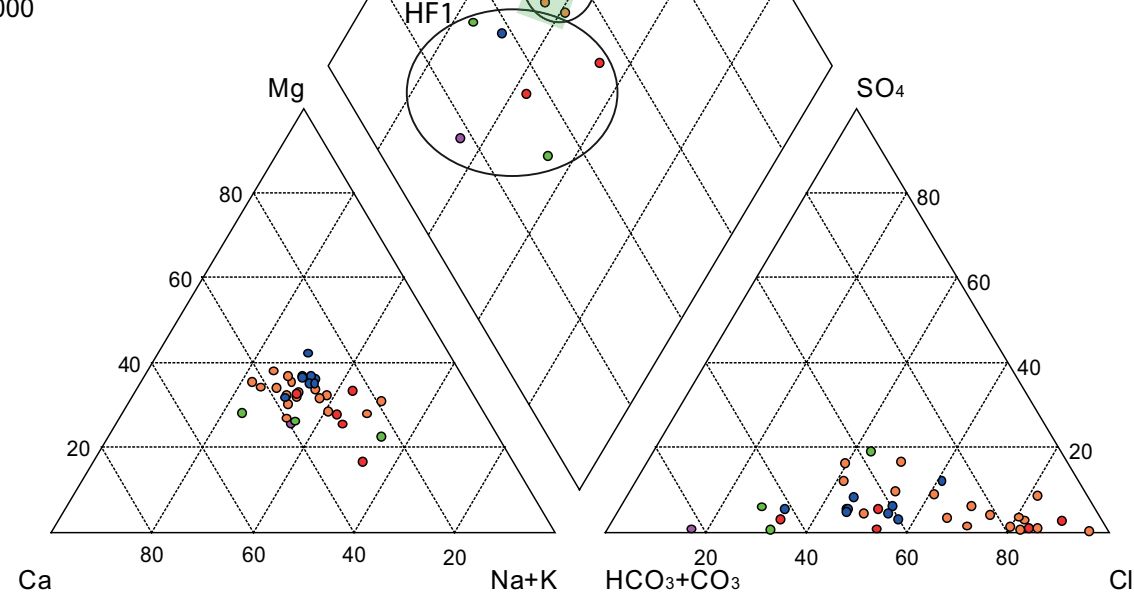

Figure 5. Piper diagram showing hydrochemical facies (HF) for surface and groundwater samples collected in the Cressbrook Creek catchment. The green and grey arrows show divergent evolutionary pathways.
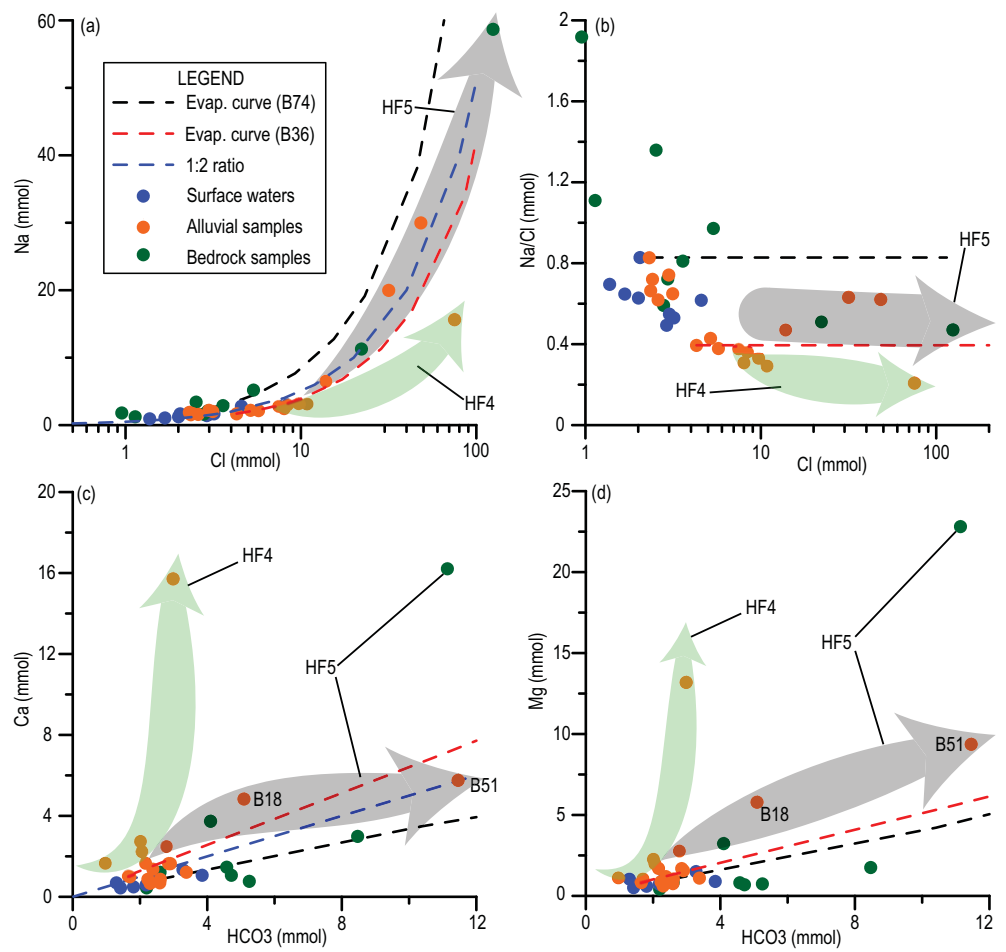

Figure 6. Major and minor ions plotted against the theoretical evaporation curves for fresh groundwater from the upper catchment (B74) and the Lower Catchment (B36). Evaporation curves were calculated using PHREEQC (Parkhurst and Appelo, 1999). 

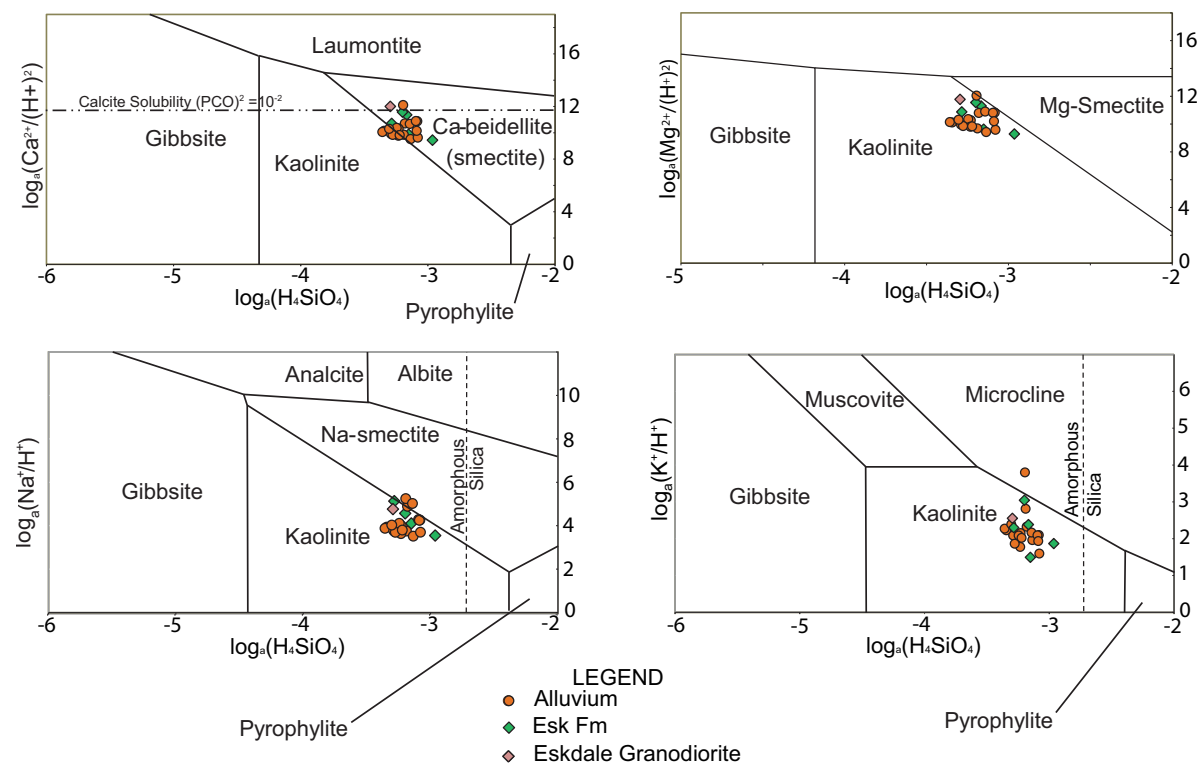

Figure 7. Groundwater silicate stability diagrams based on groundwater samples collected from the study site in 2011 for the (a) $\mathrm{CaO}-$ $\mathrm{Al}_{2} \mathrm{O}_{3}-\mathrm{SiO}_{2}-\mathrm{H}_{2} \mathrm{O}$ system; (b) $\mathrm{MgO}-\mathrm{Al}_{2} \mathrm{O}_{3}-\mathrm{SiO}_{2}-\mathrm{H}_{2} \mathrm{O}$ system; (c) $\mathrm{Na}_{2} \mathrm{O}-\mathrm{Al}_{2} \mathrm{O}_{3}-\mathrm{SiO}_{2}-\mathrm{H}_{2} \mathrm{O}$ system, including albite; and (d) $\mathrm{K}_{2} \mathrm{O}-$ $\mathrm{Al}_{2} \mathrm{O}_{3}-\mathrm{SiO}_{2}-\mathrm{H}_{2} \mathrm{O}$ system, including microcline.

to brackish (SC $369-5930 \mu \mathrm{S} \mathrm{cm}^{-1}$ ) with no clear dominant major cations and low $\mathrm{SO}_{4}$ concentrations, with $\mathrm{SO}_{4} / \mathrm{Cl}$ molar ratio ranges from 0.001 to 0.21 . The $\mathrm{Cl} / \mathrm{HCO}_{3}$ molar ratio ranges from 2.9 to 33.9 , with ratios increasing with salinity. The hydrochemistry of the bedrock groundwaters is highly variable, although the $\mathrm{Na} / \mathrm{Cl}$ ratio is generally higher than in alluvial waters (Fig. 6).

\subsection{Mineralogy and geochemical interactions with groundwater}

To assess the interaction of groundwater with minerals in the soil zone and the aquifer matrix, groundwater hydrochemical data were incorporated into silicate stability diagrams (Fig. 7) to determine the relative stability of common silicate minerals in equilibrium with groundwater collected from major bedrock aquifers (Esk Formation and the Eskdale Igneous Complex) and the alluvium (Fig. 7). The silicate stability diagrams show that kaolinite is usually in equilibrium with groundwaters from the Cressbrook Creek catchment, except for Ca-rich minerals, which are generally in equilibrium with smectite.

\subsection{Stable isotopes $\left(\delta^{2} \mathrm{H}\right.$ and $\left.\delta^{18} \mathrm{O}\right)$}

Isotopic signatures for groundwater and surface water (Table 4) are compared to rainfall data collected from Brisbane Airport and Toowoomba (Fig. 8) between May 2008 and May 2010 (Crosbie et al., 2012), and new data collected by ANSTO between June 2010 and June 2011 (Table 5). Rainfall collected from the Brisbane Airport (Fig. 1), located approximately $60 \mathrm{~km}$ east of the study site, is isotopically similar to rainfall collected from Toowoomba, which is located approximately $20 \mathrm{~km}$ to the southwest (Fig. 8a; Crosbie et al., 2012). This suggests that there is limited spatial variation in the study region, and that data from Brisbane and Toowoomba are representative of the Cressbrook Creek catchment. The Brisbane Meteoric Water Line (MWL) has a slope of 7.9 (Hughes and Crawford, 2012), which is close to the global average of 8.2 (Rozanski et al., 1993). However, the deuterium excess $(d)$ of $13.1 \%$ is higher than the global average of about $10 \%$, as observed in other coastal eastern Australian sites (Cendón et al., 2014), probably due to the influence of convective rainfall (Liu et al., 2010).

During the 12 months prior to the June 2011 sampling campaign, rainfall stable isotope signatures were depleted compared to previous rainfall events, particularly during, and immediately prior to, the flooding in January 2011. Rainfall from December 2010 and January 2011 (316 and $424 \mathrm{~mm}$ respectively; BOM, 2012) was particularly depleted in $\delta^{2}$ $\mathrm{H}\left(-30.2\right.$ and -27.8 , respectively) and $\delta^{18} \mathrm{O}(-5.34$ and -5.13 , respectively; Table 5) compared to the weighted average for rainfall, which was -3.4 and -12.7 for $\delta^{2} \mathrm{H}$ and $\delta^{18}$ O respectively (Crosbie et al. 2012). This confirms observations by Hughes and Crawford (2013), who also noted that high-precipitation rainfall events associated with east coast pressure systems in Australia can be significantly depleted. The slope of the groundwater evaporation line is approximately 3.1 (Fig. 8a). 

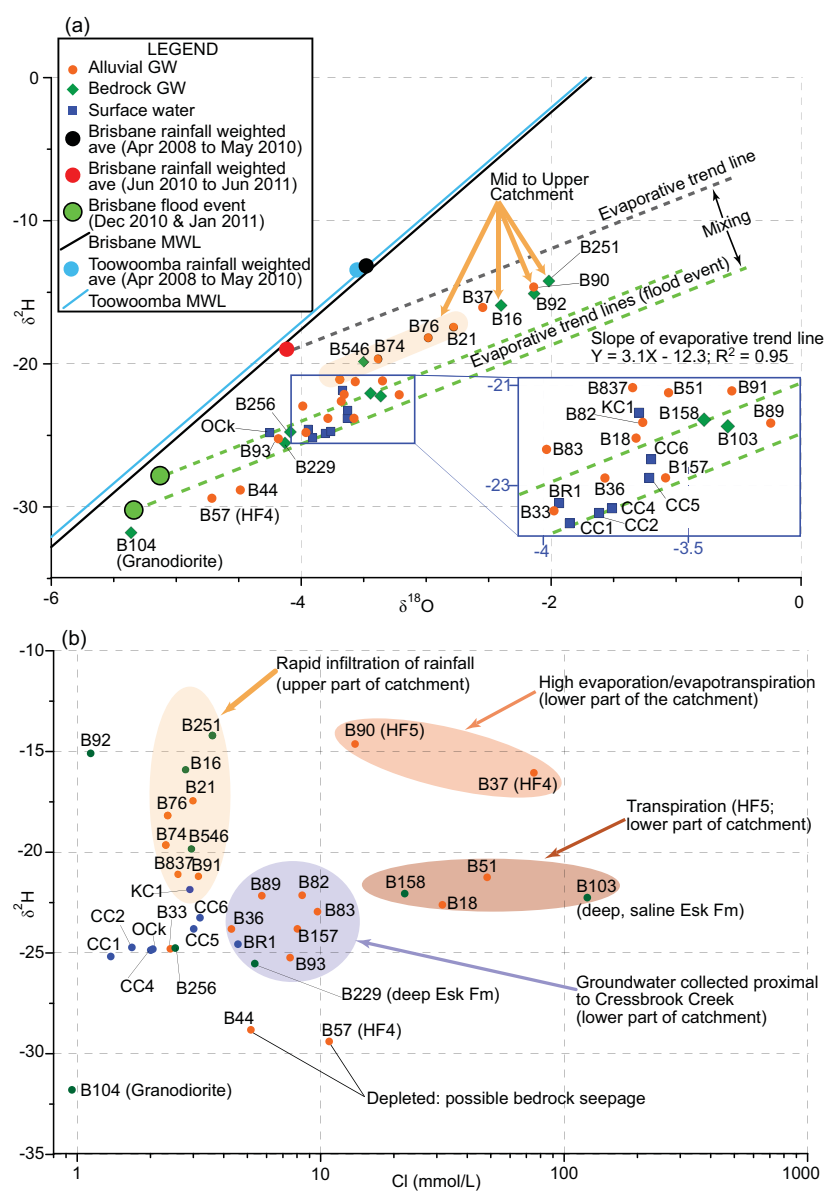

Figure 8. (a) $\delta^{2} \mathrm{H}$ versus $\delta^{18} \mathrm{O}$ values (\%o Vienna Standard Mean Ocean Water, VSMOW) compared to flood rainfall (ANSTO) and the meteoric waterline for Brisbane and Toowoomba (Crosbie et al., 2012); and (b) semi-log plot of $\delta^{2} \mathrm{H}$ (\% VSMOW) versus $\mathrm{Cl}$.

\subsection{Strontium isotopes}

Strontium isotope ratios of surface- and groundwaters in the Cressbrook Creek catchment range from 0.7042 to 0.7119 (Fig. 9), although most samples are within a narrower range of 0.7051 to 0.7078 . No measurements of the ${ }^{87} \mathrm{Sr} /{ }^{86} \mathrm{Sr}$ ratios of rainwater were conducted for the study area, and as a consequence, the ${ }^{87} \mathrm{Sr} /{ }^{86} \mathrm{Sr}$ ratios of rainfall used in this study (Fig. 9a) are based on data from elsewhere in Australia. The ${ }^{87} \mathrm{Sr} /{ }^{86} \mathrm{Sr}$ ratios of rainfall are typically similar to modern seawater (0.7092; Dia et al., 1992) near the coast, but they become progressively more radiogenic inland due to the addition of atmospheric dust. Strontium isotope measurements of rainfall from Hamilton, Casterton and Willaura in Victoria (southeastern Australia), which are located approximately 60,70 and $100 \mathrm{~km}$ from the coast respectively, were 0.7094 , 0.7097 and 0.7107 (Raiber et al., 2009). In comparison, the rainfall ${ }^{87} \mathrm{Sr} /{ }^{86} \mathrm{Sr}$ ratio measured at Woodlawoodlana located approximately 500-600 km inland in South Australia is 0.71314 (Ullman and Collerson, 1994). The Cressbrook
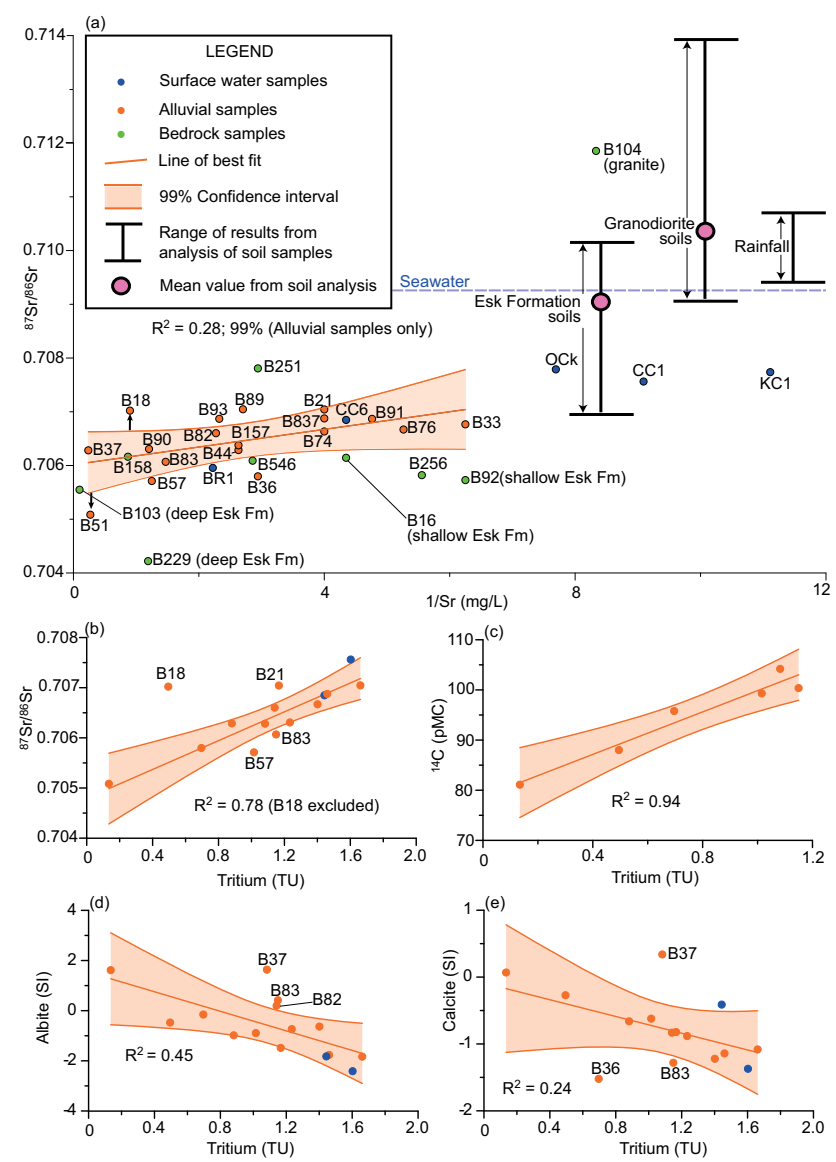

Figure 9. (a) ${ }^{87} \mathrm{Sr} /{ }^{86} \mathrm{Sr}$ versus $1 / \mathrm{Sr}$; (b) ${ }^{87} \mathrm{Sr} /{ }^{86} \mathrm{Sr}$ versus tritium; (c) ${ }^{14} \mathrm{C}$ (pMC) versus tritium; (d) saturation index (SI) for albite versus tritium; and (e) SI for calcite versus tritium. Soil analyses were performed by Douglas et al. (2007), the ${ }^{87} \mathrm{Sr} /{ }^{86} \mathrm{Sr}$ ratio for seawater was sourced from Dia et al. (1992), and the rainfall data are from Raiber et al. (2009).

Creek catchment is approximately $70 \mathrm{~km}$ from the eastern coast of Australia (Fig. 1). Assuming a similar increase of the strontium isotope ratios of rainfall with increasing distance from the coast, the ${ }^{87} \mathrm{Sr} /{ }^{86} \mathrm{Sr}$ ratios of rainfall in the Cressbrook Creek catchment may be in a similar range to those reported by Raiber et al. (2009), although it is acknowledged that local factors and temporal variability can have a substantial influence. However, the ${ }^{87} \mathrm{Sr} /{ }^{86} \mathrm{Sr}$ isotope ratio of rainfall at Cressbrook Creek should not be significantly different to the range presented in Fig. 9a, and any local variations would not affect the hydrological interpretation.

\subsection{Groundwater residence times}

Tritium and ${ }^{14} \mathrm{C}$ activities have been used to qualitatively assess groundwater residence times in the alluvium and in the surface water of Cressbrook Creek. Tritium is particularly useful for groundwater studies in the Southern Hemisphere, where ${ }^{3} \mathrm{H}$ activities of rainfall have been about 2-3 TU for 
over 20 years (Morgenstern et al., 2010; Tadros et al., 2014). In Southeast Queensland, the ${ }^{3} \mathrm{H}$ activities of rainfall have been estimated to be in the range of 1.6-2 TU for the period from 2005 to 2011 (Tadros et al., 2014). The ${ }^{3} \mathrm{H}$ activity of rainfall is no longer affected by interference from bomb tritium, but is instead controlled by natural cosmogenic production, allowing for a more accurate interpretation of groundwater residence times using a single ${ }^{3} \mathrm{H}$ measurement (Morgenstern and Daughney, 2012).

The ${ }^{14} \mathrm{C}$ activities of DIC can also provide insight into groundwater residence times and recharge processes. However, the interpretation of ${ }^{14} \mathrm{C}$ ages is often difficult, because ${ }^{14} \mathrm{C}$ activities can be altered by geochemical processes that occur in the unsaturated- and saturated zone (Plummer and Glynn, 2013). Nuclear weapons testing further complicated interpretation of ${ }^{14} \mathrm{C}$ ages in modern samples by increasing atmospheric ${ }^{14} \mathrm{C}$ activities in the 1950 s. The radiocarbon activity of alluvial groundwater in Cressbrook Creek catchment ranges from 81.12 to $104.22 \mathrm{pMC}$ (Table 4). Conventional radiocarbon ages calculated from these data range from modern to BP 1650 years. Two samples (B37 and B83) have modern uncorrected ${ }^{14} \mathrm{C}$ ages, which correlate well with their relatively high ${ }^{3} \mathrm{H}$ activities of 1.08 and $1.15 \mathrm{TU}$, respectively. This confirms that there is a substantial modern groundwater component contained in these groundwaters.

The uncorrected ${ }^{14} \mathrm{C}$ ages of the samples collected from B57, B36, B18 and B51 are BP 55, 345, 1025 and 1680 years, respectively. However, it should be noted that the ${ }^{14} \mathrm{C}$ ages have not been corrected for interactions with carbonate minerals. Tritium analyses of the same samples (B57, B36, B18 and B51) indicate that they contain a modern component (i.e. less than approximately 70 years old), with values of 1.02 , $0.70,0.50$ and $0.13 \mathrm{TU}$, respectively.

\section{Discussion}

\subsection{Origin of solutes and hydrochemical evolution}

\subsubsection{Hydrochemical facies}

Surface- and groundwaters in the upper part of the catchment are generally fresh, with SC values of $<700 \mu \mathrm{S} \mathrm{cm}^{-1}$ (Table 3; Fig. 3), whereas salinities are moderately higher in the lower catchment. Five hydrochemical facies have been identified based on a visual analysis of major ion proportions (Fig. 5). These hydrochemical facies differ slightly from those presented by King et al. (2014), which were determined by hierarchical cluster analysis (HCA) using major and minor ions and $\mathrm{pH}$. Despite these differences, there are similarities between the hydrochemical facies identified in this paper and the clusters derived using HCA. For example, Hydrochemical Facies 5 of the current paper correlates well with subclusters B2 and B3 of King et al. (2014) and Hydro- chemical Facies 3 shares similarities with subclusters A3 and A1.

Hydrochemical Facies 1 to 3 contain fresh water samples ( $\mathrm{SC}<1150 \mu \mathrm{S} \mathrm{cm}^{-1}$; Table 3 ) and samples assigned to these facies have similar concentrations of $\mathrm{Ca}, \mathrm{Mg}$ and $\mathrm{Na}$ (no dominant cation), and low $\mathrm{SO}_{4}$ concentrations (2.5$62.9 \mathrm{mg} \mathrm{L}^{-1}$ ); therefore, these three groups are mainly distinguished by the relative proportions of $\mathrm{Cl}$ to $\mathrm{HCO}_{3}$. Hydrochemical Facies 1 is mostly composed of fresh bedrock groundwater samples, but interestingly, it also includes one surface water sample $(\mathrm{OCk})$. This group is characterised by $\mathrm{HCO}_{3}$-dominated waters with molar $\mathrm{HCO}_{3}: \mathrm{Cl}$ ratios of $\leq 5$. $\mathrm{Si}$ concentrations are relatively high (median $\mathrm{SiO}_{2}$ concentration of $43 \mathrm{mg} \mathrm{L}^{-1}$ ) and low nitrate concentrations (median $\mathrm{NO}_{3}$ concentration of $0.15 \mathrm{mg} \mathrm{L}^{-1}$; Table 6). Hydrochemical Facies 2 and 3 are composed of fresh water samples with slightly higher $\mathrm{Cl}$ concentrations than samples assigned to Hydrochemical Facies $1\left(49-297 \mathrm{mg} \mathrm{L}^{-1}\right)$. Hydrochemical Facies 4 and 5 both contain brackish groundwaters (SC ranges from 1145 to $13750 \mu \mathrm{S} \mathrm{cm}^{-1}$ ) with $\mathrm{Cl}$ as the dominant anion, but the samples in Hydrochemical Facies 5 have a median $\mathrm{NO}_{3}$ concentration of $4.0 \mathrm{mg} \mathrm{L}^{-1}$, compared to those in Facies 4 which have a median $\mathrm{NO}_{3}$ concentration of just $0.19 \mathrm{mg} \mathrm{L}^{-1}$ (Figs. 5 and 6 and Table 6).

\subsubsection{Bedrock groundwater}

Bedrock groundwater samples have diverse hydrochemical compositions (Facies 1, 2 and 5; Table 3) and ${ }^{87} \mathrm{Sr} /{ }^{86} \mathrm{Sr}$ ratios (Fig. 9), reflecting the wide range of bedrock types in the study area including granodiorite, basalt, sandstone and shale. Hydrochemical end-members are highly variable due to superimposed processes such as evaporation of water from the unsaturated zone prior to groundwater recharge, transpiration, and mixing from multiple sources. The dominance of $\mathrm{HCO}_{3}$ for bedrock samples in the upper catchment (Hydrochemical Facies 1) suggests that there are several potential processes that contribute towards the observed patterns of major ion concentrations, including carbonate dissolution, oxidation of organic matter, and silicate weathering. The latter can be assessed using ${ }^{87} \mathrm{Sr} /{ }^{86} \mathrm{Sr}$ ratios and silicate stability diagrams.

Groundwaters from the Esk Formation (B229, B103 and B92; Fig. 3) typically have low ${ }^{87} \mathrm{Sr} /{ }^{86} \mathrm{Sr}$ ratios $(0.7042-$ 0.7062 ), even though the weathered soils from this formation are comparatively radiogenic (Fig. 9a) with values ranging from 0.7070 to 0.7115 and a mean of 0.7090 (Douglas et al., 2007). This suggests that ${ }^{87} \mathrm{Sr} /{ }^{86} \mathrm{Sr}$ ratios of groundwaters from the Esk Formation do not reflect the weathered whole-rock signature, but are instead probably controlled by weathering of plagioclase. Weathering of anorthite (Ca-rich plagioclase) releases ${ }^{86} \mathrm{Sr}$ (substituted for $\mathrm{Ca}$ ) into groundwater, but very little ${ }^{87} \mathrm{Sr}$ is released (McNutt, 2000), resulting in groundwaters with low ${ }^{87} \mathrm{Sr} /{ }^{86} \mathrm{Sr}$ ratios. Many other studies have also reported similar observations where groundwa- 
Table 3a. Hydrochemical data for surface and groundwater samples from Cressbrook Creek catchment.

\begin{tabular}{|c|c|c|c|c|c|c|c|c|c|c|c|c|c|}
\hline $\begin{array}{l}\text { Sampling } \\
\text { site }\end{array}$ & Date & Geology & $\begin{array}{l}\text { Sub- } \\
\text { catchment }\end{array}$ & $\begin{array}{r}\text { Depth to } \\
\text { base of } \\
\text { casing }(m)\end{array}$ & $\begin{array}{r}\mathrm{HF} \\
\text { facies }\end{array}$ & $\mathrm{pH}$ & $\begin{array}{r}\mathrm{SC} \\
\left(\mu \mathrm{S} \mathrm{cm}^{-1}\right)\end{array}$ & $\begin{array}{r}\mathrm{Eh} \\
(\mathrm{mV})\end{array}$ & $\begin{array}{r}\mathrm{Na} \\
\left(\mathrm{mgL}^{-1}\right)\end{array}$ & $\begin{array}{r}\mathrm{K} \\
\left(\mathrm{mgL}^{-1}\right)\end{array}$ & $\begin{array}{r}\mathrm{Mg} \\
\left(\mathrm{mg} \mathrm{L}^{-1}\right)\end{array}$ & $\begin{array}{r}\mathrm{Ca} \\
\left(\mathrm{mgL}^{-1}\right)\end{array}$ & $\begin{array}{r}\mathrm{Mn} \\
\left(\mathrm{mgL}^{-1}\right)\end{array}$ \\
\hline B157 & 15 Jun 2011 & Alluvium & Lower & 7.2 & 4 & 6.4 & 1145 & 80 & 57 & 11.1 & 28 & 67 & 0.58 \\
\hline B18 & 14 Jun 2011 & Alluvium & Mid & 9.5 & 5 & 6.7 & 4140 & -55 & 460 & 2.1 & 141 & 194 & 1.20 \\
\hline B21 & 14 Jun 2011 & Alluvium & Mid & 13 & 2 & 6.7 & 720 & -180 & 51 & 1.2 & 27 & 49 & 1.10 \\
\hline B33 & 14 Jun 2011 & Alluvium & Lower & 10.4 & 2 & 6.7 & 492 & -21 & 40 & 1.3 & 15 & 27 & 0.81 \\
\hline B36 & 14 Jun 2011 & Alluvium & Lower & 15.2 & 3 & 6.3 & 651 & 42 & 39 & 1.8 & 20 & 42 & 0.23 \\
\hline B37 & 22 Jun 2011 & Alluvium & Lower & 9.4 & 4 & 7.2 & 4750 & -330 & 360 & 22.0 & 321 & 630 & 0.31 \\
\hline B44 & 19 Sep 2011 & Alluvium & Lower & 12.8 & 3 & 7.0 & 708 & 35 & 51 & 0.6 & 29 & 55 & 0.02 \\
\hline B51 & 8 Jun 2011 & Alluvium & Lower & 13.7 & 5 & 6.7 & 5930 & -60 & 690 & 1.6 & 228 & 231 & 0.05 \\
\hline B57 & 19 Sep 2011 & Alluvium & Lower & 14.7 & 4 & 6.8 & 1251 & -160 & 73 & 0.8 & 55 & 110 & 0.06 \\
\hline B74 & 7 Jun 2011 & Alluvium & Upper & 7.9 & 2 & 6.6 & 587 & 45 & 44 & 1.9 & 26 & 35 & 0.04 \\
\hline B76 & 21 Jun 2011 & Alluvium & Upper & 8.0 & 2 & 6.6 & 369 & -60 & 36 & 1.3 & 19 & 28 & 0.04 \\
\hline B82 & 15 Jun 2011 & Alluvium & Lower & 14 & 3 & 6.7 & 1110 & 170 & 70 & 1.1 & 38 & 66 & 0.55 \\
\hline B83 & 15 Jun 2011 & Alluvium & Lower & 9.5 & 4 & 6.3 & 1422 & 180 & 74 & 1.0 & 49 & 90 & 0.16 \\
\hline B89 & 8 Jun 2011 & Alluvium & Mid & 12.3 & 3 & 6.4 & 938 & -25 & 50 & 1.3 & 41 & 66 & 0.61 \\
\hline B90 & 14 Jun 2011 & Alluvium & Mid & 9.4 & 5 & 6.5 & 1880 & 130 & 150 & 1.2 & 68 & 100 & 0.00 \\
\hline B91 & 21 Jun 2011 & Alluvium & Mid & 11.5 & 2 & 6.8 & 468 & -60 & 47 & 1.8 & 22 & 35 & 0.89 \\
\hline B93 & 8 Jun 2011 & Alluvium & Lower & 16.5 & 3 & 6.4 & 1082 & -5 & 65 & 1.9 & 42 & 67 & 2.10 \\
\hline B837 & 21 Jun 2011 & Alluvium & Upper & 15.8 & 3 & 6.5 & 454 & 26 & 37 & 0.9 & 26 & 40 & 0.00 \\
\hline B158 & 14 Jun 2011 & $\begin{array}{l}\text { Both alluvium } \\
\text { and bedrock }\end{array}$ & Lower & 13.6 & 5 & 6.4 & 2770 & 110 & 260 & 1.1 & 79 & 150 & 0.04 \\
\hline B92 & 15 Jun 2011 & $\begin{array}{l}\text { Both alluvium } \\
\text { and bedrock }\end{array}$ & Lower & 14.2 & 1 & 6.4 & 403 & -47 & 29 & 1.5 & 10 & 18 & 0.36 \\
\hline B103 & 15 Jun 2011 & Bedrock & Lower & 24.7 & 5 & 6.5 & 13750 & -60 & 1350 & 3.4 & 555 & 650 & 0.58 \\
\hline B104 & 19 Sep 2011 & Bedrock & Upper & 64 & 1 & 7.3 & 437 & 210 & 42 & 1.5 & 17 & 43 & 0.00 \\
\hline B16 & 15 Jun 2011 & Bedrock & Upper & 10 & 2 & 7.0 & 614 & -61 & 38 & 1.9 & 21 & 37 & 0.41 \\
\hline B229 & 21 Jun 2011 & Bedrock & Lower & $>50$ & 1 & 7.4 & 787 & -15 & 120 & 0.5 & 20 & 59 & 0.05 \\
\hline B251 & 16 Jun 2011 & Bedrock & Mid & 49.5 & 1 & 7.3 & 898 & 150 & 67 & 0.7 & 43 & 120 & 0.02 \\
\hline B256 & 21 Jun 2011 & Bedrock & Upper & 40.5 & 1 & 7.0 & 501 & 115 & 79 & 5.4 & 18 & 31 & 0.00 \\
\hline B546 & 21 Jun 2011 & Bedrock & Upper & 68.6 & 2 & 6.4 & 497 & 25 & 49 & 3.1 & 20 & 49 & 0.17 \\
\hline $\mathrm{CC} 1$ & 7 Jun 2011 & Surface water & Upper & N/A & 2 & 7.0 & 295 & 75 & 22 & 2.7 & 13 & 18 & 0.03 \\
\hline $\mathrm{CC} 2$ & 7 Jun 2011 & Surface water & Mid & N/A & 2 & 7.5 & 356 & 110 & 25 & 2.3 & 15 & 20 & 0.02 \\
\hline $\mathrm{CC} 4$ & 8 Jun 2011 & Surface water & Mid & N/A & 2 & 7.6 & 415 & 120 & 29 & 2.1 & 18 & 24 & 0.03 \\
\hline $\mathrm{CC} 5$ & 8 Jun 2011 & Surface water & Lower & N/A & 2 & 7.6 & 572 & 38 & 38 & 2.4 & 24 & 35 & 0.16 \\
\hline CC6 & 7 Jun 2011 & Surface water & Lower & N/A & 2 & 7.5 & 602 & 140 & 39 & 2.4 & 25 & 36 & 0.10 \\
\hline $\mathrm{KC} 1$ & 7 Jun 2011 & Surface water & Upper & N/A & 3 & 6.8 & 540 & 73 & 33 & 1.8 & 26 & 28 & 0.01 \\
\hline OCk & 8 Jun 2011 & Surface water & Mid & N/A & 1 & 7.2 & 543 & 110 & 39 & 0.9 & 22 & 43 & 0.02 \\
\hline BR1 & 8 Jun 2011 & Surface water & Lower & N/A & 2 & 7.0 & 829 & 110 & 65 & 2.6 & 37 & 54 & 0.06 \\
\hline
\end{tabular}

ter ${ }^{87} \mathrm{Sr} /{ }^{86} \mathrm{Sr}$ ratios are lower than the whole rock ${ }^{87} \mathrm{Sr} /{ }^{86} \mathrm{Sr}$ ratios, attributed to the dominant influence of plagioclase dissolution (e.g. Fritz et al., 1992; Richards et al., 1992; Made and Fritz, 1989). This plagioclase dissolution process is supported by geochemical evidence, which shows that Esk Formation soils are rich in smectite (Douglas et al., 2007), and that Ca-rich minerals of the Esk Formation, such as anorthite, are likely to weather to smectite (Fig. 7), whereas minerals that are rich in $\mathrm{K}, \mathrm{Na}$ and $\mathrm{Mg}$ are likely to weather to kaolinite. Therefore, it appears as though silicate weathering is a significant process affecting the major ion concentration of the bedrock groundwaters, particularly in the Esk Formation.

\subsubsection{Alluvial groundwaters}

Alluvial groundwater evolution is marked by an increase in salinity (Fig. 5), longer groundwater residence times, a decreasing ${ }^{87} \mathrm{Sr} /{ }^{86} \mathrm{Sr}$ ratio (Fig. 9b) and higher $\mathrm{Cl} / \mathrm{HCO}_{3}$ ratios (Fig. 5). The more evolved groundwaters in Hydrochemical Facies 4 and 5 have probably been subjected to higher degrees of evapotranspiration. Evaporation processes are evident from stable isotopes measurements, which show that most samples collected during this study are displaced significantly to the right of the Brisbane and Toowoomba MWL (Fig. 8a). This is in agreement with pan evaporation rates that far exceed the average annual rainfall in the catchment (Sect. 2.1).

In addition to evaporation, transpiration also appears to be an important control of groundwater salinity in some areas, as documented by elevated $\mathrm{Cl}$ and stable isotope signatures that do not show any substantial influence of evaporation (Fig. 8b). However, $\mathrm{Mg}$ and $\mathrm{Ca}$ concentrations of the samples from Hydrochemical Facies 4 are higher than would be expected from evaporation, based on modelled evaporation curves from fresh water samples from the Upper and lower catchment (Fig. 6).

Similarly, the Na concentrations are lower than expected from the evaporation curve, suggesting that the groundwater composition of samples assigned to Hydrochemical $\mathrm{Fa}$ cies 4 have been influenced by interactions with aquifer materials. As carbonate rocks are absent in the alluvium of this catchment, weathering of silicate minerals appears to be the most likely source of dissolved ions. This is also sup- 
Table 3b. Continued.

\begin{tabular}{|c|c|c|c|c|c|c|c|c|c|c|c|}
\hline $\begin{array}{l}\text { Sampling } \\
\text { site }\end{array}$ & Date & Geology & $\begin{array}{r}\mathrm{Fe} \\
\left(\mathrm{mgL}^{-1}\right)\end{array}$ & $\begin{array}{r}\mathrm{Sr} \\
\left(\mathrm{mg} \mathrm{L}^{-1}\right)\end{array}$ & $\begin{array}{r}\mathrm{Cl} \\
\left(\mathrm{mgL}^{-1}\right)\end{array}$ & $\begin{array}{r}\mathrm{SO}_{4} \\
\left(\mathrm{mg} \mathrm{L}^{-1}\right)\end{array}$ & $\begin{array}{r}\mathrm{HCO}_{3} \\
\left(\mathrm{mgL}^{-1}\right)\end{array}$ & $\begin{array}{r}\mathrm{CO}_{3} \\
\left(\mathrm{mgL}^{-1}\right)\end{array}$ & $\begin{array}{r}\mathrm{NO}_{3}-\mathrm{N} \\
\left.\mathrm{mgL}^{-1}\right)\end{array}$ & $\begin{array}{r}\mathrm{SiO}_{2} \\
\left(\mathrm{mgL}^{-1}\right)\end{array}$ & $\% \mathrm{CBE}$ \\
\hline B157 & 15 Jun 2011 & Alluvium & 7.00 & 0.38 & 284 & 41.4 & 59.2 & 0.01 & 1.26 & 38.7 & -8.6 \\
\hline B18 & 14 Jun 2011 & Alluvium & 5.30 & 1.11 & 1122 & 19.1 & 310.6 & 0.14 & 0.19 & 39.1 & 5.3 \\
\hline B21 & 14 Jun 2011 & Alluvium & 1.40 & 0.25 & 106 & 42.0 & 206.0 & 0.07 & 0.17 & 35.3 & -2.9 \\
\hline B33 & 14 Jun 2011 & Alluvium & 0.45 & 0.16 & 86 & 10.8 & 140.3 & 0.05 & 0.10 & 27.2 & -6.2 \\
\hline B36 & 14 Jun 2011 & Alluvium & 0.53 & 0.34 & 152 & 4.5 & 100.8 & 0.01 & 0.09 & 43.8 & -4.7 \\
\hline B37 & 22 Jun 2011 & Alluvium & 0.20 & 4.22 & 2663 & 17.4 & 182.1 & 0.26 & 11.68 & 37.4 & -3.4 \\
\hline B44 & 19 Sep 2011 & Alluvium & 0.32 & 0.38 & 183 & 13.0 & 145.3 & 0.09 & 3.07 & 49.4 & -4.2 \\
\hline B51 & 8 Jun 2011 & Alluvium & 8.80 & 3.71 & 1711 & 43.9 & 699.0 & 0.32 & 0.98 & 42.6 & -0.3 \\
\hline B57 & 19 Sep 2011 & Alluvium & 2.20 & 0.8 & 384 & 18.9 & 122.6 & 0.06 & 3.01 & 48.1 & -1.2 \\
\hline B74 & 7 Jun 2011 & Alluvium & 0.00 & 0.25 & 82 & 46.4 & 158.8 & 0.04 & 2.99 & 26.3 & -2.4 \\
\hline B76 & 21 Jun 2011 & Alluvium & 0.00 & 0.19 & 83 & 13.8 & 157.9 & 0.04 & 0.29 & 30.8 & -7.4 \\
\hline B82 & 15 Jun 2011 & Alluvium & 0.00 & 0.44 & 297 & 36.4 & 177.1 & 0.06 & 0.89 & 34.0 & -12.0 \\
\hline B83 & 15 Jun 2011 & Alluvium & 0.00 & 0.68 & 344 & 3.9 & 125.2 & 0.02 & 4.96 & 49.8 & -2.0 \\
\hline B89 & 8 Jun 2011 & Alluvium & 2.10 & 0.37 & 203 & 40.8 & 173.9 & 0.03 & 0.03 & 31.7 & -3.0 \\
\hline B90 & 14 Jun 2011 & Alluvium & 0.00 & 0.83 & 491 & 30.5 & 169.6 & 0.04 & 3.68 & 48.8 & -1.2 \\
\hline B91 & 21 Jun 2011 & Alluvium & 11.00 & 0.21 & 111 & 27.9 & 136.3 & 0.05 & 0.42 & 29.7 & -3.3 \\
\hline B93 & 8 Jun 2011 & Alluvium & 3.70 & 0.43 & 266 & 20.8 & 131.8 & 0.02 & 0.10 & 35.9 & -2.3 \\
\hline B837 & 21 Jun 2011 & Alluvium & 0.00 & 0.25 & 92 & 41.4 & 103.6 & 0.02 & 2.78 & 35.1 & 3.5 \\
\hline B158 & 14 Jun 2011 & $\begin{array}{l}\text { Both alluvium } \\
\text { and bedrock }\end{array}$ & 0.00 & 1.15 & 785 & 12.3 & 250.0 & 0.05 & 0.17 & 40.9 & -2.3 \\
\hline B92 & 15 Jun 2011 & $\begin{array}{l}\text { Both alluvium } \\
\text { and bedrock }\end{array}$ & 22.00 & 0.16 & 40 & 5.0 & 133.9 & 0.02 & 0.03 & 44.3 & -5.9 \\
\hline B103 & 15 Jun 2011 & Bedrock & 0.00 & 10.3 & 4415 & 193.9 & 679.6 & 0.30 & 0.02 & 29.9 & -1.0 \\
\hline B104 & 19 Sep 2011 & Bedrock & 0.05 & 0.12 & 34 & 2.5 & 287.7 & 0.38 & 0.38 & 64.8 & -3.3 \\
\hline B16 & 15 Jun 2011 & Bedrock & 0.94 & 0.23 & 99 & 14.8 & 143.5 & 0.08 & 0.24 & 37.9 & -1.7 \\
\hline B229 & 21 Jun 2011 & Bedrock & 0.00 & 0.84 & 190 & 4.1 & 279.3 & 0.46 & 0.11 & 42.3 & -1.2 \\
\hline B251 & 16 Jun 2011 & Bedrock & 0.00 & 0.34 & 127 & 37.7 & 516.8 & 0.63 & 0.42 & 30.4 & -1.8 \\
\hline B256 & 21 Jun 2011 & Bedrock & 0.00 & 0.18 & 90 & 2.9 & 320.3 & 0.18 & 0.19 & 58.8 & -8.5 \\
\hline B546 & 21 Jun 2011 & Bedrock & 0.00 & 0.35 & 104 & 62.9 & 158.4 & 0.03 & 1.33 & 29.7 & -4.8 \\
\hline $\mathrm{CC} 1$ & 7 Jun 2011 & Surface water & 0.32 & 0.11 & 49 & 12.4 & 86.6 & 0.05 & 0.16 & 15.8 & -1.6 \\
\hline $\mathrm{CC} 2$ & 7 Jun 2011 & Surface water & 0.32 & 0.12 & 59 & 10.0 & 110.3 & 0.20 & 0.17 & 17.8 & -4.9 \\
\hline $\mathrm{CC} 4$ & 8 Jun 2011 & Surface water & 0.14 & 0.28 & 71 & 10.7 & 133.1 & 0.32 & 0.04 & 19.2 & -5.2 \\
\hline $\mathrm{CC} 5$ & 8 Jun 2011 & Surface water & 0.27 & 0.21 & 107 & 11.8 & 140.8 & 0.34 & 0.06 & 20.1 & -1.0 \\
\hline CC6 & 7 Jun 2011 & Surface water & 0.13 & 0.23 & 113 & 17.6 & 144.3 & 0.25 & 0.15 & 20.7 & -2.6 \\
\hline $\mathrm{KC} 1$ & 7 Jun 2011 & Surface water & 0.00 & 0.09 & 103 & 27.9 & 79.2 & 0.03 & 0.18 & 18.8 & 2.0 \\
\hline OCk & 8 Jun 2011 & Surface water & 0.00 & 0.13 & 73 & 16.4 & 234.8 & 0.23 & 0.02 & 34.2 & -4.8 \\
\hline BR1 & 8 Jun 2011 & Surface water & 0.00 & 0.45 & 162 & 12.6 & 199.9 & 0.13 & 0.19 & 21.6 & 2.9 \\
\hline
\end{tabular}

Note: $\% \mathrm{CBE}=$ percentage charge balance error. Sub-catchment boundaries are shown in Fig. 3.

ported by a moderate correlation between ${ }^{3} \mathrm{H}$ and the saturation indices (SI) of albite $\left(R^{2}=0.45\right.$; Fig. $\left.9 \mathrm{~d}\right)$, compared to the weak correlation between ${ }^{3} \mathrm{H}$ and calcite SI $\left(R^{2}=\right.$ 0.24; Fig. 9e). Furthermore, many of these more evolved waters have $\mathrm{Ca} / \mathrm{HCO}_{3}$ ratios (and $\mathrm{Mg} / \mathrm{HCO}_{3}$ ratios) that are higher than the $1: 2$ molar ratio that could be expected from the dissolution of carbonates alone (Fig. 6; Appelo and Postma, 2005).

It is likely that this increase in $\mathrm{Ca}$ and $\mathrm{Mg}$ is augmented by dissolution of mafic minerals such as olivine, pyroxene and anorthite, which are commonly present in basaltic rocks such as those in the mid to upper catchment (Palaeozoic rocks; Fig. 3). Alluvial sediments probably contain detrital material that was eroded off these basalts, providing a source of $\mathrm{Ca}$ and $\mathrm{Mg}$ for alluvial groundwaters and surface waters in the lower part of the catchment. This is supported by XRD analyses, which show that there are significant amounts of smectite in weathered sediments sampled from Lake Wivenhoe
(Fig. 1; Douglas et al., 2007), and silicate stability diagrams (Fig. 7) demonstrate that the smectite is probably the result of the weathering of $\mathrm{Ca}$-rich minerals such as anorthite.

In contrast to Hydrochemical Facies 4, the samples from Hydrochemical Facies 5 have followed a different evolutionary pathway (Fig. 5): groundwaters that are members of Hydrochemical Facies 5 generally have longer residence times (Table 6), higher Na concentrations (Fig. 5) and a groundwater evolution that more closely follows an evaporative trend (Fig. 6). Nevertheless, the evaporation curve (Fig. 6) indicates that $\mathrm{Ca}$ and $\mathrm{Mg}$ concentrations are still higher than expected if evaporation alone was the controlling factor, suggesting that the dissolution of silicates is also an important process influencing the chemistry of these waters.

\subsection{Radiocarbon groundwater residence times}

The uncorrected ${ }^{14} \mathrm{C}$ ages of the samples collected from $\mathrm{B} 18$ and B51 are BP 1025 and 1680 years, respectively; however, 
Table 4. Water isotopic and hydrochemical data for surface- and groundwater samples from the Cressbrook Creek catchment. Saturation indices (SI) for calcite and albite were calculated using PHREEQC (Parkhurst and Appelo, 1999).

\begin{tabular}{|c|c|c|c|c|c|c|c|c|c|c|c|c|c|}
\hline $\begin{array}{l}\text { Sampling } \\
\text { site }\end{array}$ & Geology & $\begin{array}{l}\text { Sub- } \\
\text { catchment }\end{array}$ & Water type & $\delta^{18} \mathrm{O}$ & $\delta^{2} \mathrm{H}$ & $\begin{array}{r}\text { Deuterium } \\
\text { excess } \\
(d)\end{array}$ & $\begin{array}{r}\text { Tritium } \\
(\mathrm{TU})\end{array}$ & $\begin{array}{r}\delta^{13} \mathrm{C} \\
(\% o)\end{array}$ & $\begin{array}{r}{ }^{14} \mathrm{C} \\
(\mathrm{pMC})\end{array}$ & $\begin{array}{c}{ }^{14} \mathrm{C} \\
\text { Uncorrected } \\
\text { Age (BP yrs) }\end{array}$ & ${ }^{87} \mathrm{Sr} /{ }^{86} \mathrm{Sr}$ & $\begin{array}{r}\text { Calcite } \\
\text { (SI) }\end{array}$ & $\begin{array}{r}\text { Albite } \\
\text { (SI) }\end{array}$ \\
\hline B157 & Alluvium & Lower & $\mathrm{Ca}-\mathrm{Na}-\mathrm{Mg}-\mathrm{Cl}$ & -3.6 & -23.8 & 4.82 & & & & & 0.70638 & -1.68 & 1.24 \\
\hline B18 & Alluvium & Mid & $\mathrm{Na}-\mathrm{Mg}-\mathrm{Ca}-\mathrm{Cl}$ & -3.7 & -22.6 & 6.83 & 0.50 & -4.4 & 88.02 & 1025 & 0.70702 & -0.27 & -0.47 \\
\hline B21 & Alluvium & Mid & $\mathrm{Ca}-\mathrm{Mg}-\mathrm{Na}-\mathrm{HCO} 3-\mathrm{Cl}$ & -2.8 & -17.4 & 4.81 & 1.17 & & & & 0.70705 & -0.82 & -1.48 \\
\hline B33 & Alluvium & Lower & $\mathrm{Na}-\mathrm{Ca}-\mathrm{Mg}-\mathrm{Cl}-\mathrm{HCO} 3$ & -4.0 & -24.8 & 6.91 & & & & & 0.70677 & -1.16 & -0.59 \\
\hline B36 & Alluvium & Lower & $\mathrm{Ca}-\mathrm{Na}-\mathrm{Mg}-\mathrm{Cl}-\mathrm{HCO} 3$ & -3.8 & -23.8 & 6.49 & 0.70 & & 95.81 & 345 & 0.70580 & -1.52 & -0.15 \\
\hline B37 & Alluvium & Lower & $\mathrm{Ca}-\mathrm{Mg}-\mathrm{Na}-\mathrm{Cl}$ & -2.5 & -16.1 & 4.33 & 1.08 & & 104.22 & Modern & 0.70628 & 0.34 & 1.64 \\
\hline B44 & Alluvium & Lower & $\mathrm{Ca}-\mathrm{Mg}-\mathrm{Na}-\mathrm{Cl}-\mathrm{HCO} 3$ & -4.5 & -28.8 & 7.09 & 0.88 & & & & 0.70629 & -0.66 & -0.98 \\
\hline B51 & Alluvium & Lower & $\mathrm{Na}-\mathrm{Mg}-\mathrm{Cl}$ & -3.6 & -21.2 & 7.30 & 0.13 & -4.9 & 81.12 & 1680 & 0.70509 & 0.07 & 1.62 \\
\hline B57 & Alluvium & Lower & $\mathrm{Ca}-\mathrm{Mg}-\mathrm{Na}-\mathrm{Cl}$ & -4.7 & -29.4 & 8.33 & 1.02 & & 99.32 & 55 & 0.70571 & -0.62 & -0.89 \\
\hline B74 & Alluvium & Upper & $\mathrm{Mg}-\mathrm{Na}-\mathrm{Ca}-\mathrm{HCO} 3-\mathrm{Cl}$ & -3.4 & -19.6 & 7.43 & & & & & 0.70664 & -1.12 & -1.96 \\
\hline B76 & Alluvium & Upper & $\mathrm{Na}-\mathrm{Mg}-\mathrm{Ca}-\mathrm{HCO} 3-\mathrm{Cl}$ & -3.0 & -18.2 & 5.70 & 1.40 & & & & 0.70667 & -1.22 & -0.63 \\
\hline B82 & Alluvium & Lower & Ca-Mg-Na-Cl-HCO3 & -3.7 & -22.1 & 7.12 & 1.14 & & & & 0.70660 & -0.83 & 0.20 \\
\hline B83 & Alluvium & Lower & $\mathrm{Ca}-\mathrm{Mg}-\mathrm{Na}-\mathrm{Cl}$ & -4.0 & -22.9 & 8.96 & 1.15 & & 100.38 & Modern & 0.70607 & -1.28 & 0.42 \\
\hline B89 & Alluvium & Mid & Mg-Ca-Na-Cl-HCO3 & -3.2 & -22.2 & 3.57 & 1.66 & & & & 0.70705 & -1.08 & -1.83 \\
\hline B90 & Alluvium & Mid & $\mathrm{Na}-\mathrm{Mg}-\mathrm{Ca}-\mathrm{Cl}$ & -2.1 & -14.6 & 2.49 & 1.23 & & & & 0.70631 & -0.88 & -0.73 \\
\hline B91 & Alluvium & Mid & $\mathrm{Na}-\mathrm{Mg}-\mathrm{Ca}-\mathrm{Cl}-\mathrm{HCO} 3$ & -3.3 & -21.2 & 5.61 & & & & & 0.70687 & -1.07 & -1.72 \\
\hline B93 & Alluvium & Lower & $\mathrm{Mg}-\mathrm{Ca}-\mathrm{Na}-\mathrm{Cl}-\mathrm{HCO} 3$ & -4.2 & -25.2 & 8.24 & & & & & 0.70687 & -1.21 & 0.69 \\
\hline B8837 & Alluvium & Upper & $\mathrm{Mg}-\mathrm{Ca}-\mathrm{Na}-\mathrm{Cl}-\mathrm{HCO} 3$ & -3.7 & -21.1 & 8.44 & 1.46 & & & & 0.70688 & -1.14 & -1.76 \\
\hline B158 & $\begin{array}{l}\text { Both alluvium } \\
\& \text { bedrock }\end{array}$ & Lower & $\mathrm{Na}-\mathrm{Ca}-\mathrm{Mg}-\mathrm{Cl}$ & -3.4 & -22.0 & 5.51 & & & & & 0.70617 & -0.72 & 0.90 \\
\hline B92 & $\begin{array}{l}\text { Both alluvium } \\
\& \text { bedrock }\end{array}$ & Lower & $\mathrm{Na}-\mathrm{Ca}-\mathrm{Mg}-\mathrm{Fe}-\mathrm{HCO} 3-\mathrm{Cl}$ & -2.1 & -15.1 & 2.00 & & & & & 0.70573 & -1.67 & -1.55 \\
\hline B103 & Bedrock & Lower & $\mathrm{Na}-\mathrm{Mg}-\mathrm{Ca}-\mathrm{Cl}$ & -3.4 & -22.2 & 4.66 & & & & & 0.70555 & 0.18 & 1.61 \\
\hline B104 & Bedrock & Upper & $\mathrm{Ca}-\mathrm{Na}-\mathrm{Mg}-\mathrm{HCO} 3$ & -5.4 & -31.8 & 11.10 & & & & & 0.71186 & -0.06 & -0.66 \\
\hline B16 & Bedrock & Upper & $\mathrm{Ca}-\mathrm{Mg}-\mathrm{Na}-\mathrm{Cl}-\mathrm{HCO} 3$ & -2.4 & -15.9 & 3.30 & & & & & 0.70615 & -0.81 & -0.01 \\
\hline B229 & Bedrock & Lower & $\mathrm{Na}-\mathrm{Ca}-\mathrm{Cl}-\mathrm{HCO} 3$ & -4.1 & -25.5 & 7.52 & & & & & 0.70422 & 0.08 & 0.75 \\
\hline B251 & Bedrock & Mid & $\mathrm{Ca}-\mathrm{Mg}-\mathrm{Na}-\mathrm{HCO} 3-\mathrm{Cl}$ & -2.0 & -14.2 & 1.94 & & & & & 0.70781 & 0.47 & 0.19 \\
\hline B256 & Bedrock & Upper & $\mathrm{Na}-\mathrm{Ca}-\mathrm{Mg}-\mathrm{HCO} 3-\mathrm{Cl}$ & -4.1 & -24.8 & 7.95 & & & & & 0.70582 & -0.61 & 1.17 \\
\hline B546 & Bedrock & Upper & $\mathrm{Ca}-\mathrm{Na}-\mathrm{Mg}-\mathrm{Cl}-\mathrm{HCO} 3$ & -3.5 & -19.8 & 8.16 & & & & & 0.70609 & -1.21 & -0.58 \\
\hline $\mathrm{CC} 1$ & Surface water & Upper & $\mathrm{Mg}-\mathrm{Na}-\mathrm{Ca}-\mathrm{HCO} 3-\mathrm{Cl}$ & -3.9 & -25.2 & 6.10 & 1.60 & & & & 0.70756 & -1.37 & -2.41 \\
\hline $\mathrm{CC} 2$ & Surface water & Mid & $\mathrm{Mg}-\mathrm{Na}-\mathrm{Ca}-\mathrm{HCO} 3-\mathrm{Cl}$ & -3.8 & -24.7 & 5.38 & & & & & & -0.70 & -2.21 \\
\hline $\mathrm{CC} 4$ & Surface water & Mid & $\mathrm{Mg}-\mathrm{Na}-\mathrm{Ca}-\mathrm{HCO} 3-\mathrm{Cl}$ & -3.8 & -24.9 & 5.60 & & & & & & -0.44 & -2.03 \\
\hline $\mathrm{CC} 5$ & Surface water & Lower & Mg-Ca-Na-Cl-HCO3 & -3.6 & -23.8 & 5.27 & & & & & & -0.28 & -1.90 \\
\hline CC6 & Surface water & Lower & $\mathrm{Mg}-\mathrm{Ca}-\mathrm{Na}-\mathrm{Cl}-\mathrm{HCO} 3$ & -3.6 & -23.2 & 5.77 & 1.44 & & & & 0.70685 & -0.41 & -1.82 \\
\hline $\mathrm{KC} 1$ & Surface water & Upper & $\mathrm{Mg}-\mathrm{Na}-\mathrm{Ca}-\mathrm{Cl}-\mathrm{HCO} 3$ & -3.7 & -21.8 & 7.52 & & & & & 0.70774 & -1.33 & -2.29 \\
\hline OCk & Surface water & Mid & $\mathrm{Ca}-\mathrm{Mg}-\mathrm{Na}-\mathrm{HCO} 3-\mathrm{Cl}$ & -4.3 & -24.8 & 9.20 & & & & & 0.70779 & -0.35 & -1.33 \\
\hline BR1 & Surface water & Lower & $\mathrm{Mg}-\mathrm{Na}-\mathrm{Ca}-\mathrm{Cl}-\mathrm{HCO} 3$ & -3.9 & -24.6 & 6.99 & & & & & 0.70596 & -0.57 & -1.61 \\
\hline
\end{tabular}

Note: sub-catchment boundaries are shown in Fig. 3.

Table 5. Rainfall stable isotopes collected from the Brisbane Airport between June 2010 and June 2011.

\begin{tabular}{lrrr}
\hline $\begin{array}{l}\text { Sample } \\
\text { month }\end{array}$ & $\begin{array}{r}\delta^{2} \mathrm{H} \\
(\% \text { VSMOW })\end{array}$ & $\begin{array}{r}\delta^{18} \mathrm{O} \\
(\% \circ \text { VSMOW })\end{array}$ & $\begin{array}{r}\text { Monthly } \\
\text { precipitation }(\mathrm{mm})\end{array}$ \\
\hline June 2010 & 9.0 & -1.49 & 12.8 \\
July 2010 & -1.8 & -2.58 & 36.0 \\
August 2010 & -4.4 & -1.90 & 108.2 \\
September 2010 & -24.6 & -4.44 & 77.0 \\
October 2010 & -11.9 & -3.45 & 337.3 \\
November 2010 & -1.6 & -2.14 & 53.2 \\
December 2010 & -30.2 & -5.34 & 499.4 \\
January 2011 & -27.8 & -5.13 & 346.8 \\
February 2011 & -15.3 & -3.22 & 79.8 \\
March 2011 & -13.5 & -3.58 & 188.6 \\
April 2011 & 0.1 & -2.62 & 94.8 \\
June 2011 & -2.8 & -2.12 & 7.4 \\
\hline
\end{tabular}

tritium analyses indicate that this groundwater has a modern component. This discrepancy between the apparent tritium ages and the ${ }^{14} \mathrm{C}$ ages indicates that the ${ }^{14} \mathrm{C}$ activity may have been altered by carbonate dissolution, or alternatively, that there has been mixing between an older water component and a younger water component that contains tritium.

The $\mathrm{Ca}: \mathrm{Na}$ ratio of the alluvial groundwaters ranges from 0.19 to 1.00 , with an average of 0.54 and the $\mathrm{Ca} / \mathrm{Na}$ ratio of the samples from B18 and B51 are 0.19 and 0.24. This indicates that significant calcite dissolution is unlikely, as groundwaters that have experienced significant calcite dissolution generally have $\mathrm{Ca}: \mathrm{Na}$ ratios > 1 (Mast et al., 1990; Leybourne et al., 2006).

Calcite dissolution can also be assessed using the $\delta^{13} \mathrm{C}_{\mathrm{DIC}}$ composition, which is affected by interactions with organic materials and the aquifer substrate. The $\delta^{13} \mathrm{C}_{\mathrm{DIC}}$ composition of recharging groundwater is largely controlled by the composition of the decomposing plant matter. For plants that use the $\mathrm{C}_{3}$ photosynthesis, the $\delta^{13} \mathrm{C}_{\text {DIC }}$ composition of the soil is usually around $-23 \%$, whereas it is likely to be approximately $-9 \%$ in areas with $\mathrm{C}_{4}$ plants (Clark and Fritz, 1997). The study catchment is located in a water-poor area and plant productivity is often limited by the lack of water. 
Therefore, landholders commonly cultivate plants that use water efficiently, such as those that use the $\mathrm{C}_{4}$ carbon fixation pathway (e.g. corn and sorghum). However, some droughtresistant plants that use the $\mathrm{C}_{3}$ carbon fixation pathway (e.g. Lucerne) are also cultivated. Similarly, approximately $74 \%$ of grass species in the Cressbrook Creek region use the $\mathrm{C}_{4}$ carbon fixation pathway (Hattersley, 1983).

Assuming that approximately $60-90 \%$ of the ${ }^{13} \mathrm{C}$ is derived from plants that use the $\mathrm{C}_{4}$ carbon fixation pathway, soil $\mathrm{CO}_{2(\mathrm{~g})} \delta^{13} \mathrm{C}_{\text {DIC }}$ values would be approximately -15 to $-10 \%$. The $\delta^{13} \mathrm{C}_{\text {DIC }}$ value will typically increase by around $7.9 \%$ as soil $\mathrm{CO}_{2(\mathrm{~g})}$ dissociates to $\mathrm{HCO}_{3}^{-}$(at $25^{\circ} \mathrm{C}$; Clark and Fritz, 1997), which will result in groundwater with $\delta^{13} \mathrm{C}_{\text {DIC }}$ values between around -7 to $-2 \%$. The $\delta^{13} \mathrm{C}_{\text {DIC }}$ values at B18 and B51 are -4.4 and -4.9 , indicating that there has probably been no significant dissolution of old calcite, and that the uncorrected ${ }^{14} \mathrm{C}$ ages are valid. This is not unexpected, as the alluvium is composed primarily of components derived from erosion of silicate rocks, and it is unlikely to contain significant amounts of carbonate.

\subsection{Hydrological processes, recharge and the impact of flooding}

\subsubsection{Cressbrook Creek and Cressbrook Dam}

Surface water samples from Cressbrook Creek follow an evaporative trend line that intersects the meteoric waterline near the flood-generating rainfall (Fig. 8a). Cressbrook Dam was overflowing into Cressbrook Creek at the time of sampling (Toowoomba Regional Council, 2012), and water from the dam appears to be dominated by depleted heavy rainfall from December 2010 and January 2011. This is not surprising, as the storage volume of Cressbrook Dam was at record low levels (7.5\% of total capacity) in February 2010 (Toowoomba Regional Council, 2014). In addition, rainfall in the Catchment Headwaters and at Cressbrook Dam may be further depleted due to the altitude effect, as the dam is approximately $250 \mathrm{~m}$ AHD and the surrounding hills reach elevations of more than $500 \mathrm{~m}$ AHD.

Stable isotopes were a valuable tool for the identification of episodic recharge in this study. Previous studies have used stable isotopes to link groundwater recharge with high-precipitation rainfall events. For example, Cendón et al. (2010), compared alluvial groundwater isotope signatures with the weighted average isotopic signatures of rainfall events that were greater than $95 \mathrm{~mm}$. However, it is rare to use stable isotopes to assess groundwater recharge from an individual flood event.

\subsubsection{Upper catchment}

In the upper catchment, recharge to the alluvium is dominated by diffuse infiltration of rainfall rather than channel leakage (Fig. 10a and b). This is supported by evidence that
Table 6. Main features of the five hydrochemical facies (median values).

\begin{tabular}{lcrrrrr}
\hline $\begin{array}{l}\text { Hydro- } \\
\text { chemical } \\
\text { facies }\end{array}$ & $\mathrm{pH}$ & $\begin{array}{r}\mathrm{SC} \\
\left(\mu \mathrm{S} \mathrm{cm}^{-1}\right)\end{array}$ & $\mathrm{Eh}$ & $\begin{array}{r}\mathrm{SiO}_{2} \\
\left(\mathrm{mg} \mathrm{L}^{-1}\right)\end{array}$ & $\begin{array}{r}\mathrm{NO}_{3}-\mathrm{N} \\
\left(\mathrm{mg} \mathrm{L}^{-1}\right)\end{array}$ & $\begin{array}{r}{ }^{3} \mathrm{H} \\
(\mathrm{TU})\end{array}$ \\
\hline 1 & 7.2 & 522 & 113 & 43 & 0.15 & $\mathrm{~N} / \mathrm{A}$ \\
2 & 7.0 & 497 & 38 & 26 & 0.17 & 1.42 \\
3 & 6.5 & 708 & 35 & 35 & 0.18 & 1.14 \\
4 & 6.6 & 1337 & -40 & 43 & 4.0 & 1.08 \\
5 & 6.5 & 4140 & -55 & 41 & 0.19 & 0.50 \\
\hline
\end{tabular}

indicates that the stream is gaining in this part of the catchment, including field observations of groundwater discharge into the stream in the upper catchment, the sustained flow in Cressbrook Creek during years when there was no discharge from Cressbrook Dam and the increase in discharge volume between Cressbrook Dam and CC3 (Fig. 3) at the time of sampling (Sect. 2.1). Groundwater is recharged rapidly in this part of the catchment, based on the low salinity (Fig. 3). In addition, the comparison of the high groundwater ${ }^{3} \mathrm{H}$ activities (Table 4) with the rainfall ${ }^{3} \mathrm{H}$ activities presented by Tadros et al. (2014) for the period 2005-2011 for Southeast Queensland and stream waters analysed during this study confirms that a high component of groundwater consists of very recent recharge. This documents the usefulness of ${ }^{3} \mathrm{H}$ to assess recharge processes to alluvial aquifers, as previously highlighted by other studies elsewhere (e.g. Cartwright and Morgenstern, 2012; Baudron et al., 2014).

Groundwater major ions and stable isotopes from samples collected near the confluence of Cressbrook Creek and Kipper Creek are similar to the surface water sample collected from Kipper Creek (KC1; Fig. 3), suggesting that Kipper Creek receives baseflow from the alluvium in the vicinity of $\mathrm{KC} 1$. As there was no flow in Kipper Creek in the catchment headwaters at the time of sampling, the creek must have received groundwater baseflow in the Upper Catchment (i.e. near KC1). The stable isotope signature of groundwaters collected from the upper catchment and surface water from Kipper Creek is intermediate to the evaporation trends that originate from the flood-generating rainfall and the longer-term weighted average rainfall value. This suggests that recharge is sourced from the flood and from smaller rainfall events that occurred subsequent to the flood. However, the sample collected from Cressbrook Creek in the upper catchment has a more depleted stable isotope signature than other surface waters or groundwater samples from the upper catchment, probably because water in Cressbrook Creek has a high proportion of isotopically depleted flood runoff and quick flow from Cressbrook Dam (Sect. 5.3.1).

The sample collected from Oaky Creek (OCk; Fig. 3) is grouped in a different hydrochemical facies to other surface water samples. This sample has been assigned to Hydrochemical Facies 1, together with bedrock samples collected 

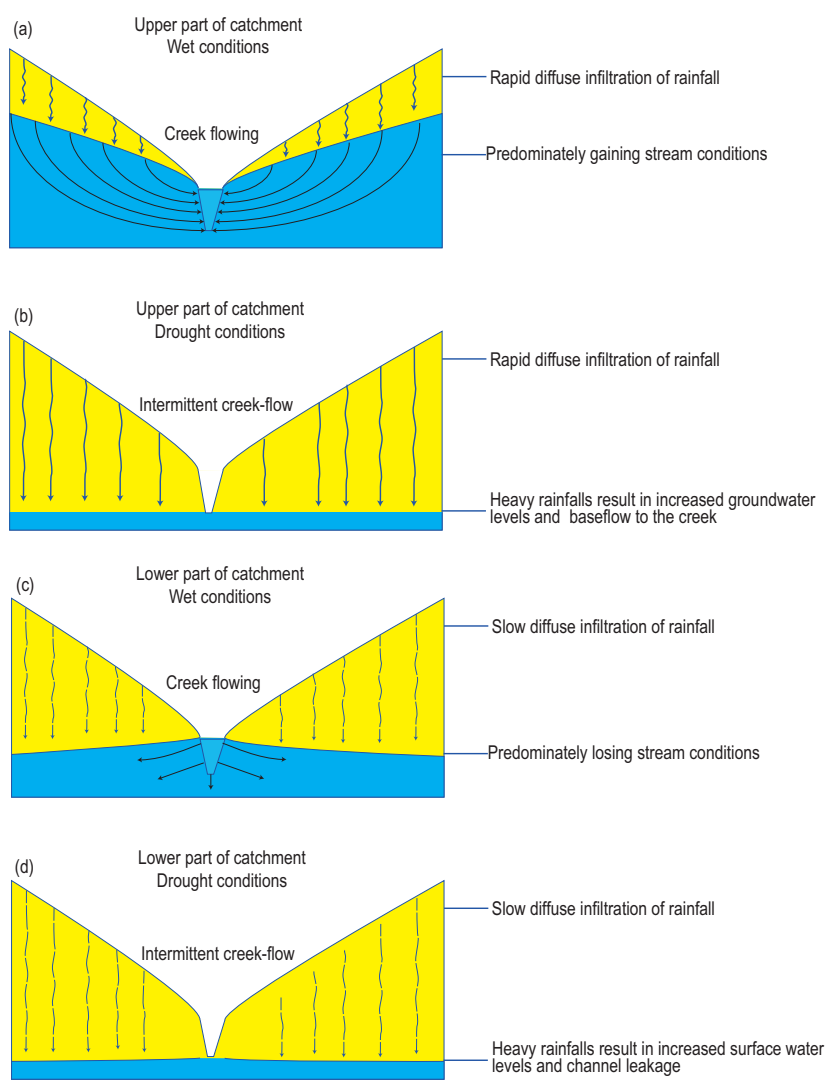

Figure 10. Conceptual model of recharge processes in the (a) upper part of catchment during wet conditions; (b) upper part of catchment during drought conditions; (c) lower part of catchment during wet conditions; and (d) lower part of catchment during drought conditions.

from the upper catchment, including a sample collected from the granodiorite foothills in the Oaky Creek sub-catchment (B104; Fig. 3). The bedrock appears to have a major impact on the chemical composition of the water in Oaky Creek, probably because the alluvial aquifer is thin and narrow in the Oaky Creek sub-catchment and because the upper layers of granodiorite are highly weathered, and therefore comparatively permeable. This permeable weathered granodiorite probably provides baseflow to Oaky Creek.

\subsubsection{Mid to lower catchment}

Most groundwaters from the lower part of the catchment also follow the evaporative trend that intersects the meteoric waterline near the flood-generating rainfall of December 2010 and January 2011, indicating that groundwater was recharged rapidly by channel leakage and/or that the flood generated substantially more recharge than other smaller rainfall events. Heavy rainfall events often have depleted stable isotope signatures, as suggested by the depleted signatures of rainfall in December 2010 and January 2011 (Table 5), and observations elsewhere (e.g. Hughes and Craw- ford, 2013). In addition, the most devastating flood to affect southeast Queensland occurred in 1974, and the $\delta^{2} \mathrm{H}$ and $\delta^{18} \mathrm{O}$ values of rainfall during this event were -64.2 and $-9.5 \%$, respectively (IAEA/WMO, 2014).

In the lower catchment, fresh groundwaters with short residence times, such as those contained in Hydrochemical Facies 2 and 3, are probably recharged rapidly by surface waters (Fig. 10c and d). These sites are generally located close to the creek and it appears as though groundwater quality is significantly improved due to interactions with surface water in this part of the catchment, confirming the observation from King et al. (2014). These groundwater-surface water interactions also appear to affect surface water compositions, as is evident from observed changes in the chemical composition of Cressbrook Creek with distance downstream. This includes (1) an increase in total dissolved salts (Fig. 3); (2) an increase in the apparent water age, as indicated by the ${ }^{3} \mathrm{H}$ activities at CC1 (Upper Catchment; $1.60 \mathrm{TU}$ ) and CC6 (lower catchment; $1.44 \mathrm{TU}$; Table 4); (3) enrichment of stable isotopes $\left(\delta^{2} \mathrm{H}\right.$ and $\delta^{18} \mathrm{O}$; Fig. 8b); and (4) a decrease in the ${ }^{87} \mathrm{Sr} /{ }^{86} \mathrm{Sr}$ ratios (Fig. 9a).

Groundwater-surface water interactions are subjected to a large degree of temporal and spatial variations due to the losing/gaining nature of the stream. Cressbrook Creek is generally losing after high-flow events, such as the flood of January 2011, but turns into a gaining stream after this event (Fig. 4). Similarly, the losing/gaining condition of the stream is likely to vary spatially as a result of changes in the streambed elevation (riffles and pools) and groundwater levels (Winter et al. 1998).

The more evolved groundwater samples from the mid and lower catchment (Hydrochemical Facies 4 and 5) were generally collected from alluvial wells that are located further away from the creeks (Fig. 3) and/or where the unsaturated zone is thick (e.g. $>10 \mathrm{~m}$ ). These sites are also located in areas where the alluvium is less permeable, suggesting that infiltrating rainfall from small rainfall events is subjected to a significant degree of evapotranspiration processes during infiltration through the unsaturated zone, and large rainfall events are probably required to generate groundwater recharge. Therefore, it is likely that these more evolved waters are predominately recharged during high-rainfall events, such as those associated with the flooding in January 2011.

\subsection{Hydraulic connectivity between bedrock and alluvium}

Tritium data show that alluvial groundwaters assigned to Hydrochemical Facies 5 have relatively long residence times (B90, B18 and B51, Table 6). In particular, the low ${ }^{3} \mathrm{H}$ activities from B18 and B51 ( 0.50 and $0.13 \mathrm{TU}$, respectively) indicate that older bedrock groundwater could be interacting with the alluvium at these sites. Furthermore, the sample collected from B158, which is screened in both the alluvium and the bedrock, is also included in Hydrochemical Facies 5. 
The sample from B90 has a stable isotope signature that indicates a substantial degree of evaporation (Fig. 8), whereas other alluvial samples assigned to Hydrochemical Facies 5 (B51 and B18) are isotopically more depleted. As previously mentioned, alluvial groundwaters assigned to Hydrochemical Facies 5 were probably subjected to significant amounts of evaporation. However, groundwater samples from sites B18 and B51 (Fig. 3) have a relatively depleted stable isotope signature considering their high $\mathrm{Cl}$ concentrations (Fig. 8), which suggests that these sites may have received seepage from depleted bedrock groundwater.

This was independently confirmed by the use of strontium isotopes, which are ideally suited for the assessment of seepage from basalts and granitic rocks to the alluvium due to their distinguishable signatures resulting from their contrasting mineralogy and the very different ages of the rocks. This study builds on work by Raiber et al. (2009), who used strontium isotopes to investigate interaction of groundwater with basalts and granitic rocks in southwestern Victoria, Australia. The groundwater sample from B18 has a radiogenic ${ }^{87} \mathrm{Sr} /{ }^{86} \mathrm{Sr}$ signature similar to groundwater sampled from the granodiorite, which forms the bedrock at this site, and sample B51 has a low ${ }^{87} \mathrm{Sr} /{ }^{86} \mathrm{Sr}$ ratio similar to the Esk Formation samples (Fig. 9a). Also, the ${ }^{14} \mathrm{C}$ groundwater ages of samples from B18 and B51 are greater than BP 1000 years, but there is detectable tritium in these samples, indicating that the water is less than approximately 100 years old. This discrepancy is consistent with mixing of old bedrock groundwater with younger alluvial groundwater.

Overall, the isotopic evidence (groundwater ${ }^{14} \mathrm{C}, \delta{ }^{13} \mathrm{C}$, stable isotopes and ${ }^{87} \mathrm{Sr} /{ }^{86} \mathrm{Sr}$ ratios) confirms that the aquifer at sites B18 and B51 receives seepage from the underlying bedrock. Interestingly, the only other two samples with ${ }^{87} \mathrm{Sr} /{ }^{86} \mathrm{Sr}$ ratios below the $99 \%$ confidence interval (Fig. 9a) are the samples from B36 and B57, which were also collected from monitoring bores overlying the Esk Formation. Furthermore, apart from B18 and B51, they are the only other two samples with non-modern uncorrected ${ }^{14} \mathrm{C}$ ages, and they have relatively depleted stable isotope signatures, suggesting that the alluvial aquifer at these sites has probably also received seepage from the underlying bedrock aquifer. Moreover, there is a strong correlation $\left(R^{2}=0.94\right)$ between ${ }^{3} \mathrm{H}$ and ${ }^{14} \mathrm{C}$ activities (Fig. 9c), which suggests that the samples from B57 and B36 have been affected by similar hydrological processes (i.e. bedrock seepage) as the samples from B51 and B18.

\section{Conclusions}

This study outlines the benefits of the simultaneous application of multiple environmental isotopes $\left({ }^{2} \mathrm{H},{ }^{18} \mathrm{O},{ }^{87} \mathrm{Sr} /{ }^{86} \mathrm{Sr}\right.$, ${ }^{3} \mathrm{H}$ and ${ }^{14} \mathrm{C}$ ) in rainfall, groundwater and surface water in combination with a comprehensive hydrochemical assessment. The aim was to study the influence of a flood on groundwater recharge and to assess the hydrological connectivity of an alluvial aquifer system with associated streams and underlying highly diverse bedrock aquifers.

Groundwater evolution is largely controlled by silicate dissolution and evapotranspiration processes, as demonstrated by the silicate stability diagrams, theoretical evaporation curves and saturation indices. In the upper catchment, rainfall is quickly recharged through relatively coarse-grained alluvial sediments. Conversely, rainwater infiltrates more slowly in the mid and lower catchment, particularly in the floodplain distal to Cressbrook Creek, as indicated by the lower tritium and ${ }^{14} \mathrm{C}$ values and the elevated salinity. In contrast, surface water leakage to the alluvial aquifer is an important mechanism for maintaining groundwater quality and for the generation of recharge in the lower part of the catchment.

The flood-generating rainfall in 2011 was isotopically more depleted $\left(\delta^{2} \mathrm{H}\right.$ and $\left.\delta^{18} \mathrm{O}\right)$ than the long-term weighted average, and groundwater from the lower part of the catchment plots along an evaporative trend line that intersects the meteoric waterline near this depleted, flood-generating rainfall of December 2010 and January 2011. This confirmed that the flood events of January 2011 generated significant recharge, whereas infiltrating water from smaller rainfall events is subject to evapotranspiration, especially in the lower part of the catchment where the unsaturated zone is relatively thick and the permeability is low. Recharge from episodic flooding is probably important in other similar settings where low-permeability sediments are incised by stream channels. Groundwater in the upper catchment follows an evaporative trend initiated from rainfall that is intermediate to the long-term weighted average rainfall and the "flood rainfall". The floods of 2011 also generated significant recharge in this part of the catchment. However, as the evaporative trend is initiated from a more enriched rainfall signature (i.e. closer to the long-term weighted average), it appears likely that smaller rainfall events also generate groundwater recharge here, probably due to the more permeable and thinner soil material in this part of the catchment. The study clearly demonstrated the value of time series rainfall stable isotope data for the identification of hydrological processes such as aquifer recharge and the generation of baseflow resulting from flooding.

The ${ }^{87} \mathrm{Sr} /{ }^{86} \mathrm{Sr}$ ratios were used to identify bedrock seepage to the alluvium at several locations. This conclusion was supported by the ${ }^{3} \mathrm{H}$ and ${ }^{14} \mathrm{C}$ data, which show that the alluvium contains a mixture of older, bedrock-derived groundwater and more recently recharged groundwater. The connectivity between the alluvium and the bedrock is likely to be spatially and temporally variable.

The complementary use of multiple isotopes and hydrochemistry of rainfall, groundwater and surface water enabled an effective assessment of hydrological processes throughout the catchment, including recharge of the alluvial deposits from surface water flows and variable bedrock aquifers, recharge specifically from flood events and an understand- 
ing of isotopic and hydrochemical parameters in the context of variable climatic conditions.

Acknowledgements. The authors acknowledge Queensland Department of Natural Resources and Mines (DNRM) for access to the groundwater database, and in particular Ashley Bleakley and Blake Topp, for their general input and field support. The authors also thank David Frizzell from Toowoomba City Council for providing surface water levels from Cressbrook Dam, and laboratory staff at the Queensland University of Technology, including Shane Russell and James Brady, for assistance with chemical analysis. Adam Hartland of the University of Waikato (formerly of the University of New South Wales) is thanked for analysing surface- and groundwater stable isotopes. The authors also acknowledge the Australian Institute of Nuclear Science and Engineering (AINSE) for the research grant that funded ${ }^{3} \mathrm{H}$ and ${ }^{14} \mathrm{C}$ analysis of groundwaters, and Robert Chisari and Geraldine Jacobsen (both ANSTO) for the analysis of ${ }^{3} \mathrm{H}$ and ${ }^{14} \mathrm{C}$, respectively. Brian Smerdon and Sebastien Lamontagne of the Commonwealth Scientific and Industrial Research Organisation (CSIRO) are also thanked for their comments, which helped to improve the manuscript. Funding by the National Centre for Groundwater Research and Training (NCGRT) is gratefully acknowledged. We would also like to thank the anonymous HESS reviewers and Ian Cartwright for their useful contributions.

Edited by: T. Blume

\section{References}

Anibas, C., Verbeiren, B., Buis, K., Chormański, J., De Doncker, L., Okruszko, T., Meire, P., and Batelaan, O.: A hierarchical approach on groundwater-surface water interaction in wetlands along the upper Biebrza River, Poland, Hydrol. Earth Syst. Sci., 16, 2329-2346, doi:10.5194/hess-16-2329-2012, 2012.

Appelo, C. A. J. and Postma, D.: Geochemistry, Groundwater and Pollution, 2nd Edn, A. A. Balkema Publishers, Leiden, the Netherlands, 2005.

Arnell, N. W. and Gosling, S. N.: The impacts of climate change on river flow regimes at the global scale, J. Hydrol., 486, 351-364, doi:10.1016/j.jhydrol.2013.02.010, 2013.

Babister, M. and Retallick, M.: Brisbane River 2011 flood event flood frequency analysis, final report, Project number 111024, Queensland Floods Commission of Inquiry, WMA Water, Brisbane, Australia, 2011.

Baudron, P., Barbecot, F., Aróstegui, J. L. G., Leduc, Y. T., Travi, Y., and Martinez-Vicente, D.: Impacts of human activities on recharge in a multilayer semiarid aquifer (Campo de Cartagena, SE Spain), Hydrol. Process., 28, 2223-2236, 2014.

Barrett, M. H., Hiscock, K. M., Pedley, S., Lerner, D. N., Tellam, J. H., and French, M. J.: Marker species for identifying urban groundwater recharge sources: a review and case study in Nottingham, UK, Water Res., 33, 3083-3097, doi:10.1016/s00431354(99)00021-4, 1999.

Barron, O. V., Crosbie, R. S., Dawes, W. R., Charles, S. P., Pickett, T., and Donn, M. J.: Climatic controls on diffuse groundwater recharge across Australia, Hydrol. Earth Syst. Sci., 16, 45574570, doi:10.5194/hess-16-4557-2012, 2012.
Boulton, A. J., Findlay, S., Marmonier, P., Stanley, E. H., and Valett, H. M.: The functional significance of the hyporheic zone in streams and rivers, Annu. Rev. Ecol. Syst., 29, 59-81, doi:10.1146/annurev.ecolsys.29.1.59, 1998.

Boulton, A. J., Datry, T., Kasahara, T., Mutz, M., and Stanford, J. A.: Ecology and management of the hyporheic zone: streamgroundwater interactions of running waters and their floodplains, J. N. Am. Benthol. Soc., 29, 26-40, doi:10.1899/08-017.1, 2010.

Bureau of Meteorology - BOM: Commonwealth of Australia Bureau of Meteorology, available at: http://www.bom.gov.au/ climate/data/, last access: 15 July 2012.

Cartwright, I. and Morgenstern, U.: Constraining groundwater recharge and the rate of geochemical processes using tritium and major ion geochemistry: Ovens catchment, southeast Australia, J. Hydrol., 475, 137-149, doi:10.1016/j.jhydrol.2012.09.037, 2012.

Cartwright, I., Weaver, T., Cendón, D. I., and Swane, I.: Environmental isotopes as indicators of inter-aquifer mixing, Wimmera region, Murray Basin, Southeast Australia, Chem. Geol., 277, 214-226, doi:10.1016/j.chemgeo.2010.08.002, 2010a.

Cartwright, I., Weaver, T. R., Simmons, C. T., Fifield, L. K., Lawrence, C. R., Chisari, R., and Varley, S.: Physical hydrogeology and environmental isotopes to constrain the age, origins, and stability of a low-salinity groundwater lens formed by periodic river recharge, J. Hydrol., 380, 203-221, 2010b.

Cartwright, I., Weaver, T. R., Cendón, D. I., Fifield, L. K., Tweed, S. O., Petrides, B., and Swane, I.: Constraining groundwater flow, residence times, inter-aquifer mixing, and aquifer properties using environmental isotopes in the southeast Murray Basin, Australia, Appl. Geochem., 27, 1698-1709, doi:10.1016/j.apgeochem.2012.02.006, 2012.

Cendón, D. I., Larsen, J. R., Jones, B. G., Nanson, G. C., Rickleman, D., Hankin, S. I., Pueyo, J. J., and Maroulis, J.: Freshwater recharge into a shallow saline groundwater system, Cooper Creek floodplain, Queensland, Australia, J. Hydrol., 392, 150163, 2010.

Cendón, D. I., Hankin, S. I., Williams, J. P., van der Ley, M., Peterson, M., Hughes, C. E., Meredith, K. T., Hollins, S. E., Graham, I. T., Chisari, R., Wong, H., and Levchenko, V.: Groundwater residence time in a dissected and weathered sandstone plateau: Kulnura - Mangrove Mountain aquifer, NSW, Australia: Aust. J. Earth Sci., 61, 475-499, 2014.

Clark, I. D. and Fritz, P.: Environmental Isotopes in Hydrogeology, Lewis Publishers, New York, USA, 1997.

Costelloe, J. F., Irvine, E. C., Western, A. W., and Tyler, M.: Identifying fluvial recharge and artesian upwards leakage contributions to arid zone shallow, unconfined groundwater, Chem. Geol., 326-327, 189-200, doi:10.1016/j.chemgeo.2012.08.014, 2012.

Cox, M. E., James, A., Hawke, A., and Raiber, M.: Groundwater Visualisation System (GVS): a software framework for integrated display and interrogation of conceptual hydrogeological models, data and time-series animation, J. Hydrol., 491, 56-72, doi:10.1016/j.jhydrol.2013.03.023, 2013.

Cranfield, L. C., Donchak, P. J. T., Randall, R. E., and Crosby, G. C.: Yarraman Special 1 : 250000 Geology, Queensland, Department of Natural Resources and Mines, Brisbane, Australia, 2001.

Crosbie, R. S., Morrow, D., Cresswell, R. G., Leaney, F. W., Lamontagne, S., and Lefournour, M.: New insights into the chemi- 
cal and isotopic composition of rainfall across Australia, CSIRO Water for a Healthy Country Flagship, Australia, 2012.

Dawes, W., Ali, R., Varma, S., Emelyanova, I., Hodgson, G., and McFarlane, D.: Modelling the effects of climate and land cover change on groundwater recharge in south-west Western Australia, Hydrol. Earth Syst. Sci., 16, 2709-2722, doi:10.5194/hess-16-2709-2012, 2012.

Department of Natural Resources and Mines - DNRM: Department of Natural Resources and Mines, Groundwater Database, Brisbane, Australia, 2012.

Department of Natural Resources and Mines, available at: http: //watermonitoring.derm.qld.gov.au/host.htm, last access: 8 October 2013.

Dia, A. N., Cohen, A. S., O'Nions, R. K., and Shackleton, N. J.: Seawater $\mathrm{Sr}$ isotope variation over the past $300 \mathrm{kyr}$ and influence of global climate cycles, Nature, 356, 786-788, doi:10.1038/356786a0, 1992.

Dogramaci, S. S. and Herczeg, A. L.: Strontium and carbon isotope constraints on carbonate-solution interactions and inter-aquifer mixing in groundwaters of the semi-arid Murray Basin, Australia, J. Hydrol., 262, 50-67, doi:10.1016/s00221694(02)00021-5, 2002.

Dogramaci, S. S., Skrzypek, G., Dodson, W., and Grierson, P. F.: Stable isotope and hydrochemical evolution of groundwater in the semi-arid Hamersley Basin of subtropical northwest Australia, J. Hydrol., 475, 281-293, doi:10.1016/j.jhydrol.2012.10.004, 2012.

Douglas, G., Palmer, M., Caitcheon, G., and Orr, P.: Identification of sediment sources to LakeWivenhoe, south-east Queensland, Australia, Mar. Freshwater Res., 58, 793-810, 2007.

Drever, J. I.: The geochemistry of natural waters, surface and groundwaterenvironments, 3rd Edn., Prentice-Hall Inc., New Jersey, USA, 1997.

Fink, D., Hotchkis, M., Hua, Q., Jacobsen, G., Smith, A. M., Zoppi, U., Child, D., Mifsud, C., van der Gaast, H., Williams, A., and Williams, M.: The ANTARES AMS facility at ANSTO, Nucl. Instrum. Meth. B, 223, 109-115, doi:10.1016/j.nimb.2004.04.025, 2004.

Fritz, B., Richard, L., and McNutt, R. H.: Geochemical modeling of $\mathrm{Sr}$ isotopic signatures in the interaction between granitic-rocks and natural solutions, in: Water-Rock Interaction, Rotterdam, the Netherlands, 927-930, 1992.

Geological Survey of Queensland and Irrigation and Water Supply Commission (GSQ and IWSC): Groundwater Resources of Queensland: Explanatory Notes, 1 : 2500000 Map, 1973.

Gleeson, T., Novakowski, K., and Kyser, K.: Extremely rapid and localized recharge to a fractured rock aquifer, J. Hydrol., 376, 496-509, 2009.

Green, T. R., Taniguchi, M., Kooi, H., Gurdak, J. J., Allen, D. M., Hiscock, K. M., Treidel, H., and Aureli, A.: Beneath the surface of global change: impacts of climate change on groundwater, J. Hydrol., 405, 532-560, doi:10.1016/j.jhydrol.2011.05.002, 2011.

Hagedorn, B., Cartwright, I., Raveggi, M., and Maas, R.: Rare earth element and strontium geochemistry of the Australian Victorian Alps drainage system: evaluating the dominance of carbonate vs. aluminosilicate weathering under varying runoff, Chem. Geol., 284, 105-126, doi:10.1016/j.chemgeo.2011.02.013, 2011.
Hancock, P. J., Boulton, A. J., and Humphreys, W. F.: Aquifers and hyporheic zones: towards an ecological understanding of groundwater, Hydrogeol. J., 13, 98-111, doi:10.1007/s10040-004-04216, 2005.

Harms, B. P. and Pointon, S. M.: Land resource assessment of the Brisbane Valley, Queensland, Department of Natural Resources, Brisbane, Australia, 1999.

Hattersley, P. W.: The distribution of C3 and C4 grasses in Australia in relation to climate, Oceologia (Berlin), 57, 113-128, 1983.

Hrachowitz, M., Bohte, R., Mul, M. L., Bogaard, T. A., Savenije, H. H. G., and Uhlenbrook, S.: On the value of combined event runoff and tracer analysis to improve understanding of catchment functioning in a data-scarce semi-arid area, Hydrol. Earth Syst. Sci., 15, 2007-2024, doi:10.5194/hess-15-2007-2011, 2011.

Hughes, C. E. and Crawford, J.: A new precipitation weighted method for determining the meteoric water line for hydrological applications demonstrated using Australian and global GNIP data, J. Hydrol., 464-465, 344-351, 2012.

Hughes, C. E. and Crawford, J.: Spatial and temporal variation in precipication isotopes in the Sydney Basin, Australia, J. Hydrol. 489, 42-55, 2013.

Hughes, C. E., Cendón, D. I., Johansen, M. P., and Meredith, K. T.: Climate change and groundwater, sustaining groundwater resources, in: Sustaining Groundwater Resources, edited by: Jones, J. J. A., Springer Netherlands, 2011.

Hvorslev, M. J.: Time lag and soil permeability in ground water observations, US Army Corps of Engineers Waterways EXP. STa. Bulletin 36, 1951.

International Atomic Energy Agency and the World Meteorological Organization (IAEA/WMO): Global Network of Isotopes in Precipitation, available at: http://www-naweb.iaea.org/napc/ih/IHS_ resources_gnip.html, last access: 2014.

King, A., Raiber, M., and Cox, M.: Multivariate statistical analysis of hydrochemical data to assess stream-alluvial aquifer connectivity during flood and drought: Cressbrook Creek, southeast Queensland, Australia, Hydrogeol. J., 22, 481-500, doi:10.1007/s10040-013-1057-1, 2014.

Kirchner, J. W., Tetzlaff, D., and Soulsby, C.: Comparing chloride and water isotopes as hydrological tracers in two Scottish catchments, Hydrol. Process., 24, 1631-1645, doi:10.1002/hyp.7676, 2010.

Knighton, A. D. and Nanson, G. C.: Waterhole form and process in the anastomosing channel system of Cooper Creek, Australia, Geomorphology, 35, 101-117, doi:10.1016/s0169555x(00)00026-x, 2000.

Kumar, U. S., Sharma, S., Navada, S. V., and Deodhar, A. S.: Environmental isotopes investigation on recharge processes and hydrodynamics of the coastal sedimentary aquifers of Tiruvadanai, Tamilnadu State, India, J. Hydrol., 364, 23-39, doi:10.1016/j.jhydrol.2008.10.004, 2009.

Lange, J.: Dynamics of transmission losses in a large and stream channel, J. Hydrol., 306, 112-126, doi:10.1016/j.jhydrol.2004.09.016, 2005.

Leybourne, M. I., Clark, I. D., and Goodfellow, W. D.: Stable isotope geochemistry of ground and surface waters associated with undisturbed massive sulfide deposits; constraints on origin of waters and water-rock reactions, Chem. Geol., 231, 300-325, 2006.

Lis, G., Wassenaar, L. I., and Hendry, M. J.: High-precision laser spectroscopy $\mathrm{D} / \mathrm{H}$ and ${ }^{18} \mathrm{O} /{ }^{16} \mathrm{O}$ measurements of mi- 
croliter natural water samples, Anal. Chem., 80, 287-293, doi:10.1021/ac701716q, 2008.

Liu, J., Fu, G., Song, X., Charles, S. P., Zhang, Y., Han, D., and Wang, S.: Stable isotopic compositions in Australian precipitation, J. Geophys. Res., 115, D23307, doi:10.1029/2010JD014403, 2010.

Made, B. and Fritz, B.: Simulation of granite dissolution at 25, 60 and 100 degrees $\mathrm{C}$ based on thermodynamic potential and kinetic laws, in: Water-Rock Interaction, Edmonton, 461-464, 1989.

Mandal, A. K., Zhang, J., and Asai, K.: Stable isotopic and geochemical data for inferring sources of recharge and groundwater flow on the volcanic island of Rishiri, Japan, Appl. Geochem., 26, 1741-1751, 2011.

Maroulis, J. C., Nanson, G. C., Price, D. M., and Pietsch, T.: Aeolian-fluvial interaction and climate change: source-bordering dune development over the past similar to $100 \mathrm{ka}$ on Cooper Creek, central Australia, Quaternary Sci. Rev., 26, 386-404, doi:10.1016/j.quascirev.2006.08.010, 2007.

Mast, M. A., Drever, J. I., and Baron, J. S.: Chemical weathering in the Loch Vale Watershed, Rocky Mountain National Park, Colorado, Water Resour. Res., 26, 2971-2978, 1990.

McNutt, R. H.: Strontium isotopes, in: Environmental Tracers in Subsurface Hydrology, edited by: Cook, P. G. and Herczeg, A. L., Kluwer Academic Publishers, Boston, MA, USA, 233-261, 2000.

Morgenstern, U. and Daughney, C. J.: Groundwater age for identification of baseline groundwater quality and impacts of land-use intensification - the National Groundwater Monitoring Programme of New Zealand, J. Hydrol., 456, 79-93, doi:10.1016/j.jhydrol.2012.06.010, 2012.

Morgenstern, U., Stewart, M. K., and Stenger, R.: Dating of streamwater using tritium in a post nuclear bomb pulse world: continuous variation of mean transit time with streamflow, Hydrol. Earth Syst. Sci., 14, 2289-2301, doi:10.5194/hess-14-22892010, 2010.

Nanson, G. C., Price, D. M., Jones, B. G., Maroulis, J. C., Coleman, M., Bowman, H., Cohen, T. J., Pietsch, T. J., and Larsen, J. R.: Alluvial evidence for major climate and flow regime changes during the middle and late Quaternary in eastern central Australia, Geomorphology, 101, 109-129, doi:10.1016/j.geomorph.2008.05.032, 2008.

Négrel, P. and Petelet-Giraud, E.: Strontium isotopes as tracers of groundwater-induced floods: the Somme case study (France), J. Hydrol., 305, 99-119, 2005.

Parkhurst, D. L. and Appelo, C. A. J.: User's guide to PHREEQC (version 2); a computer program for speciation, batch-reaction, one-dimensional transport, and inverse geochemical calculations, Water-Resources Investigations - US Geological Survey, US Geological Survey, Reston, VA, USA, 312 pp., 1999.

Parry, M. L., Canziani, O. F., Palutikof, J. P., van der Linden, P. J., and Hanson, C. E. (Eds.): Contribution of Working Group II to the Fourth Assessment Report of the Intergovernmental Panel on Climate Change, Cambridge University Press, Cambridge, UK and New York, NY, USA, 2007.

Plummer, L. N. and Glynn, P. D.: Radiocarbon dating in groundwater systems, in: Isotope Methods for Dating Old Groundwater, International Atomic Energy Agency (IAEA), Vienna, 3390, 2013.
Praamsma, T., Novakowski, K., Kyser, K., and Hall, K.: Using stable isotopes and hydraulic head data to investigate groundwater recharge and discharge in a fractured rock aquifer, J. Hydrol., 366, 35-45, 2009.

Raiber, M., Webb, J. A., and Bennetts, D. A.: Strontium isotopes as tracers to delineate aquifer interactions and the influence of rainfall in the basalt plains of southeastern Australia, J. Hydrol., 367, 188-199, 2009.

Richards, H. G., Savage, D., and Andrews, J. N.: Granite water reactions in an experimental hot dry rock geothermal reservoir, Rosemanowes test site, Cornwall, UK, Appl. Geochem., 7, 193-222, doi:10.1016/0883-2927(92)90038-5, 1992.

Rozanski, K., Araguas-Araguas, L., and Gonfiantini, R.: Isotopic patterns in modern global precipitation, Climate Change in Continental Isotopic Records, edited by: Swart, P. K., Lohmann, J., McKenzie, J., and Savin, S., American Geophysical Union, Geophysical Monograph 78, 1993.

Rushton, K. R. and Tomlinson, L. M.: Possible mechanisms for leakage between aquifers and rivers, J. Hydrol., 40, 49-65, 1979.

Scholl, M. Christenson, S., Cozzarelli, I. Ferree, D., and Jaeschke, J.: Recharge Processes in an Alluvial Aquifer Riparian Zone, Norman Landfill, Norman, Oklahoma, 1998-2000, Scientific Investigations Report 2004-5238, US Department of the Interior, US Geological Survey, 2004.

Simpson, S. C. and Meixner, T.: Modeling effects of floods on streambed hydraulic conductivity and groundwatersurface water interactions, Water Resour. Res., 48, W02515, doi:10.1029/2011wr011022, 2012.

Simpson, S. C., Meixner, T., and Hogan, J. F.: The role of flood size and duration on streamflow and riparian ground water composition in a semi-arid basin, J. Hydrol., 488, 126-135, doi:10.1016/j.jhydrol.2013.02.049, 2013.

Siwek, J. P., Zelazny, M., and Chemicki, W.: Influence of catchment characteristics and flood type on relationship between streamwater chemistry and streamflow: case study from Carpathian foothills in Poland, Water Air Soil Poll., 214, 547563, doi:10.1007/s11270-010-0445-6, 2011.

Soulsby, C., Tetzlaff, D., van den Bedem, N., Malcolm, I. A., Bacon, P. J., Youngson, A. F.: Inferring groundwater influences on surface water in montane catchments from hydrochemical surveys of springs and streamwaters, J. Hydrol., 333, 199-213, 2007.

Stuiver, M. and Polach, A.: Reporting of ${ }^{14} \mathrm{C}$ data, Radiocarbon, 19, 355-363, 1977.

Tadros, C. V., Hughes, C. E., Crawford, J., Hollins, S. E., and Chisari, R.: Tritium in Australian precipitation: A 50 year record, J. Hydrol., 513, 262-273, 2014.

Toowoomba Regional Council: Unpublished Data, c/o David Frizzell, July 2012, 2012.

Toowoomba Regional Council, Cressbrook Dam: http: //www.toowoombarc.qld.gov.au/environment-and-waste/ water-supply-and-dams/dams-a-bores/toowoomba-bulk-water/ 5311-cressbrook-dam, last access: 8 January 2014.

Ullman, W. J. and Collerson, K. D.: The Sr-isotope record of late quaternary hydrologic changes around Lake Frome, South Australia, J. Earth Sci., 41, 37-45, 2014.

Vanderzalm, J. L., Jeuken, B. M., Wischusen, J. D. H., Pavelic, P., Le Gal La Salle, C., Knapton, A., and Dillon, P. J.: Recharge sources and hydrogeochemical evolution of groundwater in al- 
luvial basins in arid central Australia, J. Hydrol., 397, 71-82, doi:10.1016/j.jhydrol.2010.11.035, 2011.

Winter, T. C., Harvey, J. W., Franke, O. L., and Alley, W. M.: Ground water and surface water, a single resource, US Geological Survey Circular 1139, US Geological Survey, Denver, USA, 1998.

Workman, S. R. and Serrano, S. E.: Recharge to alluvial valley aquifers from overbank flow and excess infiltration, J. Am. Water Resour. As., 35, 425-432, doi:10.1111/j.17521688.1999.tb03600.x, 1999.
Zahawi, Z.: Cressbrook Creek Damsites, Record 1972/33, Department of Mines, Geological Survey of Queensland, 1972.

Zhu, G. F., Li, Z. Z., Su, Y. H., Ma, J. Z., and Zhang, Y. Y.: Hydrogeochemical and isotope evidence of groundwater evolution and recharge in Minqin Basin, Northwest China, J. Hydrol. 333, 239-251, 2007. 